\title{
Assessing the Consistency of Kurdish Democratic Autonomy with International Human Rights Law
}

\author{
Gaetano Pentassuglia \\ University of Liverpool, Liverpool, UK \\ g.pentassuglia@liverpool.ac.uk
}

\begin{abstract}
Large sectors of the Kurdish movement in Turkey have progressively come to discuss, develop and/or endorse models of so-called "democratic autonomy". While there are several works in the field detailing and critiquing Turkey's policies vis-à-vis the Kurds, the international legal dimension of the Kurdish democratic autonomy proposal in its own right has received far less attention to date. The present article seeks to fill this gap by reflecting upon the internal coherence and consistency of the democratic autonomy argument in light of international law standards and practice, with particular reference to internal self-determination in Turkey. I argue that any future settlement of the Kurdish question will require not only Turkey's compliance with its own human rights obligations, but also the Kurdish movement's ability to negotiate the accommodation of its aspirations in ways that are consistent with international human rights law.
\end{abstract}

\section{Keywords}

democratic autonomy - Kurds - self-government - Turkey - international law self-determination

\section{Introduction: The Faces of the Kurdish Question}

The Kurdish communities in Turkey and across the wider Kurdistan region have gradually articulated their demands on the states that partly overlap this historical region (primarily Turkey) for what has been often referred to as the 
"democratic solution" to the Kurdish question. ${ }^{1}$ Broadly speaking, the different and largely interwoven iterations of pro-Kurdish claims over time have involved the end of military confrontations or otherwise repressive policies, broad ideas of democratisation, and forms of decentralisation of power or decision-making authority. ${ }^{2}$

Prompted by the initial configurations of the democratic solution fostered by Abdullah Öcalan, the historical leader of the Kurdistan Workers' Party (PKK), in the 1980 on and 199os, large sectors of the Kurdish movement have progressively come to discuss, develop and/or endorse models of so-called "democratic autonomy" in Turkey and beyond. Indeed, the PKK leadership and its subsequent political constellations have insisted that such form of autonomy should be seen in the broader context of what they call "democratic confederalism", namely the wider grassroots-based and self-rule-based restructuring of the Middle Eastern states where the Kurds live - not only Turkey, but Syria, Iraq and Iran too. ${ }^{3}$

1 I am most grateful to Cenzig Gunes, Jan Klabbers, Markku Suksi, Azi Chalabi and the anonymous reviewers for helpful comments on an earlier draft of this article. I should hasten to clarify that, in light of regional variations, I shall speak of a "Kurdish movement" to refer, more narrowly, to the entire political spectrum of Turkey-based entities that are seeking a permanent settlement of the Kurdish question, regardless of their different ramifications and connotations. It encompasses established pro-Kurdish political parties whose agenda includes, but is not limited to, the articulation of Kurdish claims. In a similarly synthetic vein, I shall speak of a "Kurdish argument" or "Kurdish claims" in order to capture the overarching gist of the Kurdish position in Turkey, unless differences or nuances within the Kurdish movement ought to be noted.

2 For useful historical accounts, see e.g. Janet Klein, 'The Minority Question: A View from History and the Kurdish Periphery', in Will Kymlicka and Eva Pfösti (eds.), Multiculturalism and Minority Rights in the Arab World (Oxford University Press, Oxford, 2014) p. 27; David Romano and Mehmet Gurses (eds.), Conflict, Democratisation, and the Kurds in the Middle East: Turkey, Iran, Iraq, and Syria (Palgrave Macmillan, London, 2014); Cengiz Gunes, The Kurdish National Movement in Turkey: From Protest to Resistance (Routledge, London, 2012); Cengiz Gunes and Welat Zeydalioğlu (eds.), The Kurdish Question in Turkey: New Perspectives on Violence, Representation, and Reconciliation (Routledge, London, 2014).

3 See below, section 2. Consistent with our premise (supra note 1), it should be noted that the article does not discuss the democratic autonomy proposal in the context of each of those states; although the repression of Kurdish demands is a typical feature of such states' policies throughout history (for a wide range of human rights issues, see e.g. Stefan Oeter, 'The Kurds between discrimination, autonomy and self-determination', in Peter Hilpold (ed.), Autonomy and Self-determination: Between Legal Assertions and Utopian Aspirations (Edward Elgar Publishing Ltd, Cheltenham, 2018) p. 208), the current analysis assumes the different social and political circumstances in which Kurdish issues have arisen over time, and thus does not engage with the question of how, apart from Turkey, the Kurdish argument affects the specific legal/institutional context of those states, whatever its regional ramifications on a conceptual/ historical level. For these distinctive historical trajectories, see e.g Romano and Gurses (eds.), 
Much has been written on Turkey's (and the other above states') chronic hostility to the accommodation of Kurdish rights following the partitioning of Kurdistan after the collapse of the Ottoman Empire. ${ }^{4}$ From an international law and human rights perspective, the discussion has been built mainly around the interpretation of the 1923 Treaty of Lausanne, which effectively entrenched the rise of the Republic of Turkey and its relationship to neighbouring states, and/or the multiple human rights issues linked to the politics of repression against the Kurds that punctuated that country's various military coups. ${ }^{5}$ Such matters have continued to seriously taint Turkey's engagement with international (especially European) organisations and the international community at large, including the most recent reescalation of the military conflict in south-east Turkey and northern Syria. ${ }^{6}$

Less known - arguably understated - in human rights/international law discourse is the extent to which the conceptual structure of the Kurdish argument, as captured by the idea of democratic autonomy, interfaces with the conceptual and practical underpinnings of international human rights categories and standards. In fact, while there are several works in the field detailing and critiquing Turkey's policies vis-à-vis the Kurds, the international legal

supra note 2; Mohammed M.A. Ahmed, Iraqi Kurds and Nation-Building (Palgrave Macmillan, London, 2012); Abbas Vali, Kurds and the State in Iran (Tauris, London, 2011).

4 A key element of the analysis is the exclusionary nature of the (Kemalist/Turkish and Arab) nationalisms that emerged in post-Ottoman territories and the various Kurdish responses: see e.g. Klein, supra note 2, p. 44; David McDowall, A Modern History of the Kurds (Tauris, London, 2004) p. 115 et seq.

5 See, for example, Baskin Oran, 'The Minority Concept and Rights in Turkey: The Lausanne Peace Treaty and Current Issues', in Zehra F. Kabasakal Arat (ed.), Human Rights in Turkey (University of Pennsylvania Press, Philadelphia, 2006) p. 35; Charles G. MacDonald and Carole A. O'Leary, Kurdish Identity: Human Rights and Political Status (University Press of Florida, Gainesville, 2007); Derya Bayir, 'Turkey, the Kurds, and the legal contours of the right to self-determination', 1 Kurdish Studies (2013) p. 5. However, for a broader perspective, see the early assessment by Ove Bring, 'Kurdistan and the Principle of Self-Determination', 35 German Yearbook of International Law (1992) p. 157; and more recently Oeter, supra note 3.

6 Mustafa Gurbuz, 'Turkey's Kurdish Conflict has Surged Again. Here is Why', The Washington Post, 21 March 2017, <https://www.washingtonpost.com/gdpr-consent/?destination=\%2fnew s\%2fmonkey-cage\%2fwp\%2f $2017 \% 2 f_{03} \% 2$ f $21 \% 2$ fhow-competition-helped.-then-hurtkurds-in-turkey\%2f\% $\%$ f>, visited on 10 October 2019; Patrick Kingsley, 'Who Are the Kurds, and Why Is Turkey Attacking Them in Syria?', The New York Times, 14 October 2019, <https:// www.nytimes.com/2019/10/14/world/middleeast/the-kurds-facts-history.html>, visited on 18 October 2019; see also Hakan Kolcak, 'A More but not Fully Constructed. Arena: A Critical Analysis of the AKP's Policy toward Kurdish Ethno-Cultural Rights (2002-2014), 5 The Age of Human Rights Journal (2015) p. 63; Edel Hughes, 'The European Union Accession Process: Ensuring the Protection of Turkey's Minorities?', 17 International Journal on Minority and Group Rights (2010) p. 561. 
dimension of the Kurdish democratic autonomy proposal as such (i.e. regardless of Turkey's position, or more general Kurdish claims or their purely political or ideological dimensions) has received far less attention to date. What follows seeks to fill this gap by reflecting upon the internal coherence and consistency of the democratic autonomy argument in light of international law standards and practice, with particular reference to internal self-determination in Turkey.

The following analysis is thus structured around two fundamental issues: the evolving position of the Kurds in Turkey in relation to democratic autonomy, and the conceptual significance of such a position in terms of international human rights standards and self-determination practice. I will first discuss the Kurdish argument as such (section 2) and then explore it, in three steps, against the international legal context (sections 3-4), including a legal understanding of the Kurds as a group (section 3.1), the substantive human rights categories that operate as a background to the Kurdish argument (section 3.2), and finally an assessment of their implications for internal selfdetermination in Turkey (section 4). I will argue that while several key elements of the democratic autonomy proposal closely engage international law and the evolving law of self-determination in particular, other elements of that proposal may require further conceptual refining as part of a continually adjustable set of institutional goals to be pursued in negotiation with the government.

\section{$2 \quad$ What Do the Kurds in Turkey Want?}

The numerous political iterations of Kurdish claims over the past two decades have built the democratic solution to the Kurdish question around at least three, largely interwoven, conceptual categories. One is the notion of "community" or "nation"; the other is the concept of "democracy"; and the third one, which encompasses both of them, revolves around the articulation of "autonomy". Each of these concepts (or clusters of concepts) is of course used variously in the political theory and sociology literature to refer to several collective and/or institutional dimensions. This is not the place for dissecting such multiple, often overlapping, understandings. Suffice it to say that each of them attracts core meanings or basic distinctions, whether it is the politically or culturally defined community (political and cultural nationalism) - further conceptualised as instrumentally or intrinsically worthy, related or unrelated to state-building, exclusionary or supportive vis-à-vis other groups' aspirations, insulated or integrated into a wider diverse communal context - a view of 
democracy as quintessentially defined by popular control over decisionmaking by those affected by it, on the basis of equality, or, relatedly, a minimal view of autonomy as some form of self-governance by a group over matters of importance to it. ${ }^{7}$

Interestingly, in the context of the Kurdish position, all of these categories (or elements of them), are designed to interact to varying degrees with the substate, state and trans-national or trans-border levels in ways that essentially map into the territorial configuration of Kurdistan and the states that inherited Kurdish population groups following its partition at the end of the First World War.

The Kurdish argument builds upon the idea of a Kurdish community, or indeed a Kurdish nation, by looking at both the substantive meaning of Kurdish identity and the wider societal context in which such identity should be recognised. For one thing, the rights of the Kurdish "people" and the quest for the recognition of its "national identity" feature in important texts of the PKK and its subsequent institutional ramifications. ${ }^{8}$ On the other hand, the general

7 The purpose of this section is conceptual and explanatory rather than normative, in the sense that I shall not attempt to fit the Kurdish argument into any specific theoretical (normative) conception of those categories, although elements of the argument may selfevidently resonate more clearly with some such conceptions than with others. See e.g. Michael Ignatieff, Blood and Belonging (в ВС Books, London, 1993); on nationalist conceptions and aspirations, see recently Neil Walker, 'Teleological and Reflexive Nationalism in the new Europe', in Jacint Jordana, Michael Keating, Axel Marx and Jan Wouters (eds.), Changing Borders in Europe: Exploring the Dynamics of Integration, Differentiation and Self-Determination in the European Union (Routledge, London, 2019) p. 163; for a fuller articulation of this longstanding debate, see infra note 13. For an integrated vision of a 'community of communities', see also Azadeh Chalabi, National Human Rights Action Planning (Oxford University Press, Oxford, 2018) pp. 17-19; Dwight Newman, Community and Collective Rights: A Theoretical Framework for Rights Held by Groups (Hart Publishing, Oxford, 2011). On democracy as popular control and political equality, see David Beetham, Democracy and Human Rights (Polity Press, Cambridge, 1999), ch. 1; see more broadly, the overview by Mark E. Warren, 'Democracy and the State', in John S. Dryzek, Bonnie Honig and Anne Phillips (eds.), The Oxford Handbook of Political Theory (Oxford University Press, Oxford, 2006) p. 382. On a minimal understanding of autonomy as a political-constitutional mechanism, see the osce High Commissioner on National Minorities, The Lund Recommendations on the Effective Participation of National Minorities in Public Life \& Explanatory Note, September 1999; the non-territorial version of autonomy is often linked, in the political science literature, to the national cultural autonomy model proposed by Karl Renner and Otto Bauer in the face of a collapsing AustroHungarian Empire: for discussion, see Ephraim Nimni (ed.), National Cultural Autonomy and Its Contemporary Critics (Routledge, London, 2005).

8 See, for example, the position expressed in the PKK's monthly magazine Serxwebûn: 'Demokratik Özerklik', 301 Serxwebûn (2007) p. 57 (as translated by Cenzig Gunes, 'Unpacking the "Democratic Confederalism" and "Democratic Autonomy": Proposals of Turkey's Kurdish Movement', in Olgun Akbulut and Elçin Aktoprak (eds.), Minority Self-Government in Europe 
institutional model underpinning the Kurdish position is not the nation-state, as Öcalan and the broader Kurdish leadership see it, but what they call a "democratic nation" or a "democratic national community". ${ }^{9}$ While a strictly monocultural view of the nation-state does not tolerate group diversity and works towards assimilating minority groups into the majority's practices, Öcalan's conceptual view of a democratic nation is not defined by a "single language, culture, religion and interpretation of history", but by "plurality and communities as well as free and equal citizens existing together and in solidarity".10

Crucially, a nation is understood, on this view, as "a community of people who share a common mindset", and a democratic nation one that rests on the "self-government of communities and individuals who share a similar mindset through their own will"." Politically at least, this entails an inclusive view of national identity both in Turkey (and the other states where the Kurds live) and within Kurdish societies themselves. In other words, the articulation of nationhood in this context seeks to combine the distinctiveness of Kurdish identity (language and culture more generally) within and across state boundaries, with a wider liberationist project that speaks to all groups within Kurdis$\tan$ (e.g. across gender and ethnicity), and the states where Kurdish-populated areas exist. ${ }^{12}$ In this sense, neither statehood nor ethnocentrism can explain the Kurdish argument. Rather, the latter's ambition is to provide a model of pluralist society that moves beyond exclusivist ethno-nationalism, identityblind (seemingly neutral) civic views of the state, or a combination of both. ${ }^{13}$

and the Middle East: From Theory to Practice (Martinus Nijhoff Publishers, Leiden, 2019) p. 260).

9 Abdullah Öcalan, Demokratik Uygarlik Çözümü, Fifth Volume (Amara Yayıncllı, 2015) pp. 52-53, 469 (as translated by Gunes, supra note 8, p. 252; Naif Bezwan, 'Addressing the Kurdish Self-Determination Conflict: Democratic Autonomy and Authoritarianism in Turkey', in Ephraim Nimni and Elçin Aktoprak (eds.), Democratic Representation in Plurinational States: The Kurds in Turkey (Palgrave Macmillan, London, 2018) p. 59 et seq., at pp. 66-67.

10 Abdullah Öcalan, The Political Thought of Abdullah Öcalan: Kurdistan, Woman's Revolution and Democratic Confederalism (Pluto Press, London, 2017) p. 108.

11 Ibid.

12 This appears to be the case both in relation to Öcalan's largely Marxist-oriented and libertarian thinking, and the more recent political manifesto of the HDP, <http://www.hdp .org.tr/parti/parti-programi/8> (2012), visited on 1o December 2019 .

13 For the complex debate over the intertwining of political and cultural dimensions to the concept of nation, see e.g. Anthony Smith, The Ethnic Origins of Nations (Blackwell Publishers Ltd, Oxford, 1986); Federico Chabod, L'idea di nazione (Editori Laterza, Bari, 1962); Ernest Gellner, Nations and Nationalism (Blackwell Publishing, Oxford, 1983); David Miller, On Nationality (Oxford University Press, Oxford, 1997); Benedict Henderson, Imagined Communities: Reflections on the Origin and Spread of Nationalism (Verso, London, 1983); 
This approach to Kurdish nationalism closely relates to a broad understanding of democracy as a political and institutional framework within which the accommodation of Kurdish claims is thought to be possible. The core idea of democracy effectively operates as a free-standing notion that is then deployed in various argumentative directions. As probably most clearly articulated in the early 2000 by the Kongra-Gel (Kurdistan People's Congress), democracy is not seen as a tool "to further the interest or domination of a class, nation, ethnic or religious group"; rather, it stands for a political regime "in which every group has the right to self-expression regardless of their power". ${ }^{14}$ Such emancipatory and cross-cutting view of democracy feeds into at least three types of narratives: 1) the constitutional restructuring of Turkey (and the other relevant states) along the lines of a systemic democratisation that involves the constitutional recognition of distinct group identities, primarily (though not exclusively) in the form of language and education rights; 2) the democratisation of Kurdish society whereby a tailored form of self-administration - from local villages up to higher-level self-governing structures - is expected to deepen and pluralise people's identity and ability to participate more effectively in decision-making; and 3) the development of Kurdistan as a case of democratic confederalism to the extent that such form of self-administration coordinates sub-state governing levels across the region and generates representation and participation of all groupings within Kurdistan. ${ }^{15}$

The deployment of "democracy" as a free-standing political-institutional category essentially aims to generate empowerment and participation for the Kurds and other groups regardless - indeed, short of - a Kurdish state. This is especially clear in the context of democratic confederalism that is understood as a way of realising a degree of self-government in Kurdistan without

Isaiah Berlin, 'Nationalism: Past Neglect and Present Power', in Henry Hardy (ed.), Against the Current: Essays in the History of Ideas (The Hogarth Press, London, 1979) p. 333; Yael Tamir, Why Nationalism (Princeton University Press, Princeton, 2019); Walker, supra note 7.

14 Kongra Gele Kurdistan (Kongra-Gel), Program, Tuzuk ve Kararları (Weşanên Serxwebûn, 2004) p. 9o. The entity was created following the PKK's cessation of all political activity in 2002, and the abolishment of the immediate successor to it in 2003, the Kurdistan Freedom and Democracy Congress. The vision of democracy articulated in its programme is nevertheless linked to a wider project of "radical democracy" initiated by the PKK: see Ahmet Hamdi Akkaya and Joost Jongerden, 'Confederalism and autonomy in Turkey: The Kurdistan Workers' Party and the reinvention of democracy', in Gunes and Zeydalioğlu (eds.), supra note 2, p. 186.

15 Although the disentanglement of such narratives can be useful for analytical purposes, a significant degree of overlap amongst the conceptual categories that underpin those narratives can be found in various articulations of the Kurdish argument, as it normally presents the idea of self-government on the back of a more general call for societal pluralism. 
challenging the territorial sovereignty of the states that variously incorporated its lands..$^{16}$ This view of "non-state democracy", ${ }^{17}$ far from rejecting the existing state structures, becomes effectively a call for a longer-term negotiated solution with Turkey and the other states based on the recognition of pluralism and grassroots-level involvement in political processes. It is meant to operate as democracy below the surface of the existing state, not in the context of a newly established one. It should be noted that not all Kurdish movement political actors have embraced the idea of transnational democratic confederalism or are otherwise actively pursuing it. ${ }^{18}$ However, virtually all such actors do not link the notion of democracy or democratisation up with any form of secessionist claim. Whether it is transnational in character or, as is most often the case, a project specific to Turkey, ${ }^{19}$ "non-state self-government" of the sort indicated above is presented as a model of political participation that can account for diversity within and outside of the Kurdish community and ultimately promote revised constitutional frameworks that affect state societies from within.

That this is in fact the key objective of the Kurdish argument as it stands is borne out by the conceptualisation of autonomy - indeed, democratic autonomy - as an internal institutional arrangement designed to achieve a suitable accommodation of Kurdish demands while at the same time enhancing the democratic credentials and legitimacy of the state as a whole. There are essentially two layers to the democratic autonomy concept, primarily or exclusively related to Turkey. One is the recognition of the identity of the Kurdish community and other groups through a new constitutional regime based on a revised, pluralistic notion of Turkey's national identity or nationality, which allows for the free and equal manifestation and protection of those national and religious group identities that are actively nurtured within society. ${ }^{20}$ This central strand of the concept goes as far as to advocate forms of autonomy that

16 Abdullah Öcalan, The Political Thought of Abdullah Öcalan: Kurdistan, Woman's Revolution and Democratic Confederalism (Pluto Press, London, 2017) p. 47; this is reflected in the Preface to the Union of Kurdistan Communities' so-called 'Contract', adopted in 2005: кск, кск Sözleşmesi, < https://tr.wikisource.org/wiki/KCK_S\%C3\%B6zle\%C5\%9Fmesi>, visited on 15 December 2019 .

17 Gunes, supra note 8, p. $25^{8}$.

18 As noted by Cenzig Gunes and Çetin Gürer, "[in] contrast with the PKK's objective of building a pan-Kurdish hybrid entity in the Middle East, for the HDP, the objective of democratic autonomy is to reform Turkey's political system" ('Kurdish Movement's Democratic Autonomy Proposals in Turkey', in Nimni and Aktoprak (eds.), supra note 9, p. 165.

19 Ibid.

20 This is most clearly expounded in the HDP's political manifesto: see supra note 12; see also Selahattin Demirtaş, "The Middle East, The Kurdish Peace Process in Turkey, and Radical Democracy', 13 Turkish Policy Quarterly (2015) p. 27. 
include state-wide community representative bodies tasked with managing aspects of the group's identity such as mother tongue education, thereby establishing forms of self-administration based on group membership instead of territorial settlement. ${ }^{21}$ Whatever the actual scope of the arrangement linked to historical and political circumstances, its incorporation into the democratic autonomy concept rests on bottom-up participation in decision-making as the litmus test of genuine group recognition by the state.

The other aspect of this concept involves a broad process of decentralisation of power across Turkey, which is expected to translate into self-governing local and regional units. The claim made by various key pro-Kurdish political parties, of which the HDP is the latest iteration, essentially points to the creation of territorially-defined self-governing regions across the country as a way of decentralising (and thus democratising) the constitutional structure of the state. A significant implication of this would be also the bringing together of Kurdish-majority provinces ("benign" gerrymandering) on the basis of predefined competences agreed upon as part of a comprehensive agreement with the central government. ${ }^{22}$ Three points are worth noting here. Firstly, the rolling of territorial and non-territorial solutions into the democratic autonomy concept reflects Kurdish demography in Turkey, since a significant number of Kurds lives in western Turkey rather than south-eastern Anatolia. Secondly, where taken in the context of a democratic nation and democracy itself as outlined above, the articulation of autonomy as a political and institutional category remains within the parameters of an overall constitutional restructuring of Turkey; it is not intended to herald the establishment of some form of sub-state ethnocracy in disguise so much as to challenge the culturally monolithic and tightly centralist view of Turkey as a nation-state. ${ }^{23}$ Thirdly, the local self-government model that is being proposed - from communes or villages to provincial councils - also represents essentially a model of grass-root associationism that can operate (partly at least) regardless of the entrenchment of self-government within a revised constitutional framework. ${ }^{24}$

21 Gunes and Gürer, supra note 18, p. 168. Unsurprisingly, the idea of non-territorial selfgovernance has resonated with discussions about the early model of national cultural autonomy proposed by Austro-Marxists Renner and Bauer at the turn of the last century (see supra note 7 ).

22 For an overview of political party positions, see Gunes, supra note 8, pp. 262-264.

23 For insightful reviews of the development of Turkish nationalism as a project of ethnic homogenisation, see, for example, Perry Anderson, 'Kemalism', 30 London Review of Books (2008) p. 3; Cenzig Gunes and Welat Zeydalioğlu, 'Introduction: Turkey and the Kurds', in Gunes and Zeydalioğlu (eds.), supra note 2, p. 1; Derya Bayir, Minorities and Nationalism in Turkish Law (Routledge, London, 2013).

24 The point here is that this form of civil society networking and coordination can be partly supported by private law-based forms of "personal autonomy" protected by general 
In the end, the argument for a democratic solution to the Kurdish question seeks to combine, in dynamic ways, identity recognition, institutional reform, and enhanced rights protection for all. It appeals, somehow simultaneously, to Kurdish belonging and inter-communal respect and social intersectionality, to democracy within an existing state jurisdiction and democracy without statebuilding (i.e. as direct, "non-state", involvement in decision-making through self-government). While the gist of the political argument (against some of the above conceptualisations of first-order categories) is reasonably clear, despite its multidimensionality and ultimate hybridity (for example, across parameters of liberal and radical democracy), the conceptual and institutional implications of that argument raise, as noted, the question of its overall consistency with international law. One can argue that, aside from Turkey's policies and obligations in the field, for the democratic autonomy concept to function, it requires a legal understanding of the Kurds as a group and of the extent to which their demands can and should be accommodated. With this in mind, the next two sections will, respectively, address the position of the Kurds as an ethno-cultural or ethno-national community (section 3.1), examine the more substantive international (human rights) framework and categories as a background to the Kurdish argument (section 3.2), and finally discuss the interface between democratic autonomy and internal self-determination in Turkey (sections 4.1-4)..$^{25}$

\section{International Legal Dimensions of the Kurdish Argument}

\subsection{Conceptualising the Kurds in Turkey}

The most typical starting point in almost all articulations of Kurdish claims is the distinctiveness of Kurdish identity as a collective socio-cultural reality in Turkey and across the region, despite linguistic variations across Kurdistan and specific socio-political circumstances in the states where the Kurds live. ${ }^{26}$

associative freedoms. For this minimal understanding of autonomy, see Markku Suksi, 'Personal Autonomy as Institutional Form - Focus on Europe Against the Background to Article 27 of the ICCPR', 15 International Journal on Minority and Group Rights (2008) pp. 160-161. More broadly, on the role of civil society networks as a significant contextual factor in addressing power deficits and realising human rights, see Chalabi, supra note 7, pp. 29-31.

25 The following analysis does not assume, let alone focus on, any prospect of Kurdish independence across the region, though it does provide insights into external selfdetermination elements that can be usefully contrasted with the implications of the democratic autonomy proposal.

26 For the broader context, see supra notes 2, 3. Despite a common western Iranian linguistic origin, Kurdish dialects, of which the most widely spoken ones are Kurmanji (primarily in 
Unsurprisingly, this strong and time-honoured sense of communal belonging, one that survived the fragmentation of Kurdish areas in the first post-war territorial reconfiguration of the Middle East, has traditionally fuelled claims to self-determination for the Kurds as a people or nation. ${ }^{27}$

In Turkey, which is the focus of our discussion, the claim has taken on special significance as sectors of politically active Kurds have linked such claim to the Kurdish community being a "constitutive nation" or otherwise one of the founding peoples of the Republic of Turkey given their major contribution to the early 1920s War of Independence alongside the "Turks". ${ }^{28}$ Partly in support of this approach is the pre-Lausanne Constitution of modern Turkey approved by the Grand National Assembly in 1921, which did not specifically endorse this characterisation of the Kurds, yet did adopt a fairly inclusive understanding of "nation", "people" and "self-determination". Crucially, it featured in Article 11 a commitment to provincial autonomy via a specific autonomy law that was primarily meant in the eyes of the drafters to benefit Kurdish-populated lands. ${ }^{29}$ In the context of the more recent democratic autonomy proposals the point has been broadly echoed in the specific demand, mainly by the PKK, for the constitutional recognition "of the national identity of the Kurdish people" as a basis for a new political union of the state. ${ }^{30}$

This strand of the Kurdish argument appears problematic to the extent that it aims to be grounded on the right to self-determination of "peoples" in

southeast Turkey) and Sorani (primarily in northern Iraq) do not coalesce around a single 'official' Kurdish language. See also Martin Van Bruinessen, Agha, Shaik and State: The Social Political Structures of Kurdistan (Zed Books Ltd, London, 1992).

27 See, for example, Abbas Vali, Kurdish Nationalism: Identity, Sovereignty and the Dialectics of Violence in Kurdistan (Tauris, London, 1996); Hurst Hannum, Autonomy, Sovereignty, and Self-Determination: The Accommodation of Conflicting Rights (University of Pennsylvania Press, Philadelphia, rev. ed., 1996) p. 178.

28 Oran, supra note 5, p. 44. He aptly distinguishes Turkish sub-identity within the Ottoman Empire from the transformation of that identity into the supra-identity of the Republic of Turkey (ibid., pp. 50-52); Büşra Ersanlı and Günay Göksu Özdoğan, 'Obstacles and opportunities: recent Kurdish struggles for political representation and participation in Turkey', 35 Southeastern Europe (2011) pp. 67-68.

29 Olgun Akbulut, 'Legal Background of Autonomy Arrangements in Turkey from Historical Perspective', in Akbulut and Aktoprak (eds.), supra note 8, p. 235. Article 1 of the 1921 Constitution vested sovereignty in the "nation without condition", and the system of government in self-determination "by the people". In 1920, Atatürk had promised "Turks and Kurds" to be part of a pluralistic notion of nation, involving respect for Kurdish identity and autonomy in the regions where they predominantly lived (see Anderson, supra note 23, p. 9). For the later decline of this stance, see Bayir, supra note 23, ch. 4. 
international law. Providing a historical overview of this right within the international legal system is well beyond the purposes of this article. ${ }^{31}$ However, some critical points about the tensions within the notion of "peoplehood" should be made here. When taken in isolation from the wider ramifications of the democratic autonomy concept, the Kurdish "co-founding" national view can be traced back to Wilsonian self-determination in its attempt, including in the post-Ottoman territories, to combine political and cultural nationalism, democracy and group identity, by either supporting consent-based nationbuilding projects or underwriting the accommodation of national groups within wider political and cultural communities. ${ }^{32}$ In this sense, that view functions (conceptually at least) not only on the back of the 1921 Constitution of Turkey, but also the pre-Turkey commitment to the autonomy, and possibly independence, of culturally or nationally distinct Kurdistan under the 1920 Treaty of Sévres. ${ }^{33}$

When we look closely at the evolution of self-determination in international law in the post-war period and across much of the 2oth century, what we see, though, is the fairly regular subordination of the peoplehood or nationhood claim (in the broadly cultural sense) to considerations of territorial stability. It essentially meant that those groups who viewed themselves as cultural nations were either denied a transition to separate statehood on purely national grounds, ${ }^{34}$ or required to accommodate other national groups within a new

31 For a wide range of perspectives, see among others James Crawford, 'The Right of SelfDetermination in International Law: Its Development and Future', in Philip Alston, Peoples' Rights (Oxford University Press, Oxford, 2001) p. 6; James Summers, Peoples and International Law: How Nationalism and Self-Determination Shape a Contemporary Law of Nations (Martinus Nijhoff Publishers, Leiden, 2007).

32 US President Wilson's Fourteen Points Address to Congress, 8 January, 1918, point XII (regarding the "autonomous development" of the nationalities under now Turkish rule); Alfred Cobban, National Self-Determination (Oxford University Press, London, 1944); Michla Pomerance, 'The United States and Self-Determination: Perspectives on the Wilsonian Conception', 70 American Journal of International Law (1976) p. 1; Michla Pomerance, SelfDetermination in Law and Practice: The New Doctrine in the United Nations (Martinus Nijhoff Publishers, The Hague, 1982).

33 Treaty of Sévres, 10 August 1920, Part III, Section III, Kurdistan (Articles 62 to 64).

34 In the famous Aaland Islands case from the early 1920s, the League of Nations did not endorse the national argument as a self-sufficient basis for state-making in international law. See e.g. The Aaland Islands Question (On Jurisdiction), Report of the International Committee of Jurists, League of Nations Official Journal, Special Supplement No. 3 (1920); The Aaland Islands Question (On the Merits), Report by the Commission of Rapporteurs, League of Nations Council Document B7 21/68/106 (1921). 
state ${ }^{35}$ or effectively subsumed into a broader territorial unit in which their identity played (legally and politically) no specific role. ${ }^{36}$ It is true that all of this happened in the context of claims to state-making rather than internal constitutional restructuring. However, the broader point is that the overarching territorial paradigm endorsed - de jure or de facto - by the international community at various historical junctures in addressing self-determination disputes constantly struggles to reconcile with a more substantive, cultural understanding of national identity that generally underlies claims to national self-determination.

The upshot of this pattern has been a certain level of hybridity, or even ambiguity, around the notions of "people" or "nation" in international legal discourse, not only because of the frequently contested nature of its precise subjective membership and/or objective, territorial extension, ${ }^{37}$ but also, and more pragmatically, because of the rather typical unwillingness on the part of adjudicators and policy-makers (and obviously states alike) to settle this sort of controversy by definitional fiat. In the Reference case, for example, the Supreme Court of Canada walked a thin line between conventional advocacy of the right of a "people" to self-determination and the recognition of the legitimacy of national claims as a central assumption of the way in which those conversations between the central government and Quebec should be conducted. It conceded that self-determination may benefit a portion of the state's population and that self-determination itself is normally fulfilled through internal arrangements, as opposed to territorial changes in sovereignty. As the

35 See e.g. the Polish Minority Treaty, 28 June 1919 (as a legal framework for Polish national independence).

36 From a post-colonial perspective, see, for example, Anthony Anghie, 'Nationalism, Development and the Postcolonial State: The Legacies of the League of Nations', 41 Texas International Law Journal (2006) pp. 455-462; Mohammad Shahabuddin, 'Post-colonial Boundaries, International Law, and the Making of the Rohingya Crisis in Myanmar', 9 Asian Journal of International Law (2019) p. 334. Interestingly, from a political science standpoint, Walker Connor was one of the first scholars to bring this element into focus: 'Nation-Building or Nation-Destroying?', 24 World Politics (1972) pp. 319-55. In terms of modern Turkey, Martin van Bruinessen notes (mutatis mutandis) that "[i]t is surprising how long scholarship on Turkey has allowed itself to be led by the self-view of the Kemalist elite and has managed to evade the question of ethnicity in Republican Turkey" (Walker Connor, Race, culture, nation and identity politics in Turkey: Some comments, presented at the Mica Ertegün Annual Turkish Studies Workshop on Continuity and Change: 'Shifting State Ideologies from Late Ottoman to Early Republican Turkey, 1890-1930', Department of Near Eastern Studies, Princeton University, 24-26 April, 1997).

37 One of the clearest socio-historical misfits is the one between "nation" as a culturally homogenous entity and "state" as a political-institutional mechanism: hardly any state is the reflection of a single such entity. 
Court ruled out Quebec's unilateral right to secession, it crucially noted that, for the problem at hand to be addressed, establishing the status of the Quebec population as a "people", or a "people" amongst other "peoples" within Quebec, was not necessary.38

The case tells us something very important about the fine, yet real dividing line between convincingly articulating an argument about peoplehood in (international) law and dealing with, acknowledging, the co-existence of sub-state national claims as part of the legal process. In practice, the Court's finding of a constitutional duty on the parties to negotiate the terms of selfdetermination affecting the population as a whole appealed to the sociocultural reality of the groups in question rather than their precise legal standing from a self-determination perspective. ${ }^{39}$ In the far more dramatic case of the 1990s war in Bosnia, the EC Badinter Commission similarly eschewed the peoplehood argument in addressing the legality of the self-determination claim made by the Bosnian Serbs, yet acknowledged a whole host of rights under international and national law that benefitted them as "population", "minority" and/or "ethnic group" within the state. ${ }^{40}$

From this specific point of view, the Catalan case does not reflect an entirely different pattern, despite the fact that its logic wholly derives (on the face of it) from Article 2 of the Spanish Constitution. ${ }^{41}$ The Constitutional Court of Spain has dismissed the claim that the Catalan people are a "people" in a legal sense, but has still recognised the historical or cultural representation of Catalonia as a "national reality" to be a "perfectly legitimate idea".42 This idea links up, directly or indirectly, with a "legitimate political aspiration" of Catalan citizens

38 Constitutional Court of Canada, Reference Re Secession of Quebec [1998] 2 S.C.R. 217, para. 125 .

39 The Court generically appeals to the "whole of the people or peoples resident within the territory": ibid., para. 130.

40 European Community Arbitration Commission, Opinion No. 2, 11 January 1992, 31 International Legal Materials (1992) p. 1497. One should also note that in the later, post-Yugoslavia, Kosovo case, the International Court of Justice refrained from recognising the population of Kosovo, or indeed the Kosovar Albanians, as a people in a legal sense: Accordance with International Law of the Unilateral Declaration of Independence in Respect of Kosovo, 22 July 2010, ICJ, Advisory Opinion, paras. 51, 56, 82, 89, 105, 109, <https://www.icj-cij.org/ files/case-related/141/141-20100722-ADV-o1-oo-EN.pdf>, visited on 10 January 2019.

41 For a good overview of the case, see Lucía Payero-López and Ephraim Nimni, 'The Liberal Democratic Deficit in Minority Representation: The Case of Spain', in Gaetano Pentassuglia (ed.), Ethno-Cultural Diversity and Human Rights: Challenges and Critiques (Martinus Nijhoff Publishers, Leiden, 2018) p. 90, at p. 104 et seq.

42 CCJ 31/2010, 28 June 2010. Thus, for the Court, there is no such thing as a "people of Catalonia" for the purpose of its Statute of Autonomy and of defining Catalonia as a "nation" (as opposed to "nationality") in a legal and constitutional sense (Legal Bases, 9, 12). 
to decide the future status of Catalonia as long as this is achieved in accordance with some constitutional parameters. ${ }^{43}$ Here again, the attempt to identify in law some procedural way forward on the path to reconciling competing claims does not depend on establishing the claimant as a "people" but is rather linked to a process that can give legitimacy (and legality) to sub-state national groups' standing and voice.

In short, while there is nothing in international law that prohibits an extension of the "people" category to communities who view themselves as nations, either through specific state legislation/constitutional settlement or specific international instruments, ${ }^{44}$ a prudential reading of the Kurdish argument would militate against taking the constitutional recognition of the Kurds as a "nation" or "constitutive nation" as a non-negotiable sine qua non, i.e. as the only way of achieving a credible measure of "national" selfdetermination within Turkey. Rather than pursuing group status precision as the end state (or starting point) of constitutional developments, the Kurdish argument should be seen through the lens of the various forms of legal and institutional recognition of sub-state groups' aspirations (e.g. including language, forms of jurisdiction, or symbolic representation) as a legitimate sociocultural reality.

From an international law perspective, this in practice means working at the intersection of group existence within a wider political community, and alongside other groups, and an adjustable set of political and legal objectives. While this approach can and should foster an overarching, more pluralist understanding of Turkey's national identity, seemingly in the spirit of the 1921 Turkish Constitution, it also seeks to maximise, more pragmatically and more immediately, the impact of the broad variety of group accommodation mechanisms recognised by international human rights law on the gradual (potentially incremental) accommodation of Kurdish demands, including key elements of the democratic autonomy proposal.

Most of these mechanisms are ordinarily associated with national minorities, or minority nations, or otherwise cultural communities traditionally established within certain territories, such as indigenous peoples. ${ }^{45}$ Although

43 For a reconstruction of the constitutional position and its potential, see Eduardo J. Ruiz Vieytez, 'Minority Nations and Self-determination: A Proposal for the Regulation of Sovereignty Processes', 23 International Journal on Minority and Group Rights (2016) p. 402, at pp. 411-413.

44 For the hybrid and highly contingent nature of some such ad hoc developments, see Gaetano Pentassuglia, 'Do Human Rights Have Anything to Say about Group Autonomy?', in Pentassuglia (ed.), supra note 41 , at pp. 144-146.

45 See, for example, Marc Weller (ed.), Political Participation of Minorities: A Commentary on International Standards and Practice (Oxford University Press, Oxford, 2010); Christine 
sectors of the Kurdish movement have voiced concerns about the characterisation of the Kurds in Turkey as a national minority, since they see it as a secondclass status against the role of a co-founding nation that they claim - something of a replica of the second-class status afforded to non-Muslim millets (Greek Orthodox, Armenian, and Jewish) under Ottoman rule ${ }^{46}$ - there are a number of reasons that indicate why such concerns are not necessarily well-placed. The millet system, for all its imperfections and the inequality on which it rested vis-à-vis the Muslim majority within the Ottoman Empire, has nevertheless attracted praise for its ability to recognise the value of group autonomy, with minimal interference from the central authorities. ${ }^{47}$ It was not based on "minority rights" (or rights of "minorities" or "minority" status) per se, and yet it provided a model that, if reworked in line with contemporary human rights standards, could represent a useful basis for addressing at least some of the non-territorial cultural claims that underlie the democratic autonomy proposal. ${ }^{48}$

It should also be noted that the core understanding of a national minority in international law (i.e. regardless of whatever variations on the concept may be claimed in human rights practice or deemed acceptable to states) arguably goes a long way towards valuing the role of the group as historically integral to the state-making process, consistent with the Kurdish argument. For example, Recommendation 1735 on the concept of "nation", adopted in 2006 by the Council of Europe's Parliamentary Assembly, describes national minorities or communities as a "cofounding entity" of the nation-state, a by-product of multiple reallocations of sovereign power across the international system throughout history. It calls for acceptance of the right "of all individuals to belong to the nation that they feel they belong to, whether in terms of

Bell, On the Law of Peace: Peace Agreements and the Lex Pacificatoria (Oxford University Press, Oxford, 2008) ch. 11; Tove Malloy and Francesco Palermo (eds.), Minority Accommodation through Territorial and Non-Territorial Autonomy (Oxford University Press, Oxford, 2015).

46 For this critique, see the works cited in supra note 28.

47 See, for example, a useful review by Ephraim Nimni, "The Conceptual Challenge of NonTerritorial Autonomy', in Ephraim Nimni, Alexander Osipov and David Smith (eds.), The Challenge of Non-Territorial Autonomy: Theory and Practice (Peter Lang AG, Bern, 2013) pp. 17-19.

48 Ibid.; Elçin Aktoprak, "The Kurdish Opening and the Constitutional Reform: Is There any Progress?', 9 European Yearbook of Minority Issues (2012) p. 643, at p. $65^{1}$ et seq.; Latif Tas, 'The Myth of the Ottoman Millet System: Its Treatment of Kurds and a Discussion of Territorial and non-Territorial Autonomy', 21 International Journal on Minority and Group Rights (2014) p. 497; Jan Erk, 'Non-Territorial Millets in Ottoman History', in Malloy and Palermo (eds.), supra note 45, p. 119. 
citizenship or language, culture and traditions", as well as non-territoriallybased structures endowed with legal personality. 49

Other factors justify a reasonably fluid and cross-cutting legal articulation of Kurdish nationalist aspirations. While the democratic autonomy proposal does not need a "people" in a legal sense to function, the democratic autonomy concept most clearly rests on the participation of the Kurdish community in decision-making processes, especially those that are of direct concern to it. Graduated forms of political participation are very much part of the contemporary minority rights framework and must thus be taken seriously as models of accommodation in multinational or multicultural states. ${ }^{50}$ At the same time, the argument can work dynamically below and above the core idea of the Kurds as a national community. The Treaty of Lausanne, for example, despite its restriction of minority status to "non-Muslim" minorities, can and should be read to include the Kurds as "Turkish nationals of non-Turkish speech" (under Article 39) for the purpose of protecting their language rights in a number of areas of public and private life (judicial process, commerce, religion, media, etc.). ${ }^{51}$ This field of standards becomes further amplified as we look at general human rights norms that, though by definition not specific to groups like the Kurds, can still generate group-related dimensions of protection. ${ }^{52}$ Such readings effectively suggest the need for an open-textured legal positioning of the Kurds along a continuum that goes from a set of individual rights in distinctive circumstances to a robust institution of self-government - both of which are implied or openly pursued by the democratic autonomy proposal.

When contrasting the peoplehood or nationhood claim with the broader non-ethnocentric notion of democratic nation (and ultimately state) outlined in section 2, one can reasonably argue that, whatever the (understated) tension between the two ideas, the democratic autonomy proposal works more effectively, from a human rights perspective, when it flexibly relates the Kurds as a socio-cultural reality to various multi-layered, legal iterations of Kurdish claims and institutional goals, and how they can interact, and potentially overlap, with other communal visions within Turkey (people of Turkey, Turks,

49 Council of Europe, Parliamentary Assembly, The concept of "nation", Recommendation 1735 (2006), 7th Sitting, 26 January 2006, paras. 10, 12.

5o See supra note 45; OsCE Lund Recommendations, supra note 7; OSCE High Commissioner on National Minorities, The Ljubljana Guidelines on Integration of Diverse Societies \& Explanatory Note, November 2012, pp. 18-20, 45-51.

$5^{1} \quad$ For a similar argument, see e.g. Oran, supra note 5 , at pp. 43-44.

52 Gaetano Pentassuglia, 'Protecting Minority Groups through Human Rights Courts: The Interpretive Role of the European and Inter-American Jurisprudence', in Ana Vrdoljak (ed.), The Cultural Dimension of Human Rights, Eu I Collected Courses (Oxford University Press, Oxford, 2013) p. 73 . 
Kurds, other minorities, other minorities within Kurdish areas, etc.). This dynamic positioning is effectively reinforced by the interplay of several international law principles and categories that, directly or indirectly, impact the Kurdish articulation of democratic autonomy. They include at least notions of territorial integrity, democracy and pluralism, as well as the broader concept of participation. I will next discuss each of them in turn, in order to explore the international legal background to the Kurdish argument (section 3.2), followed by an assessment of its implications for internal self-determination in Turkey (section 4).

\subsection{Legal Categories behind Democratic Autonomy}

There is hardly any articulation of group accommodation mechanisms in international law that does not remind us of the principle of territorial integrity that all such mechanisms must respect. This legal and policy mantra permeates not only international instruments that openly refer to the right to self-determination, but also those texts that fail to do so. ${ }^{53}$

When coupled with the default position taken by the international community against the breaking up of states, the logic of those international standards is two-pronged: they rule out secessionist claims within the legal and policy framework they themselves provide; and, relatedly, they are very much an integral part of a wider consensus that views the unilateral pursuit of secession (or independence) by sub-state groups as incompatible with the territorial stability of states. In practice this signifies the lack of a freestanding unilateral right of sub-state groups to secession rather than a general prohibition of secession or independence under international law. ${ }^{54}$

Separate statehood might be achieved as a result of negotiations with the central authorities or otherwise a constitutional process (whether or not under international scrutiny) that leads up to territorial changes in sovereignty backed by referenda. ${ }^{55}$ However unlikely it is for the central government to give a straightforward consent to such a process, the alternative possibilities of effecting secession on the ground through an extra-legal (typically or most

53 See e.g. Declaration on Principles of International Law Concerning Friendly Relations and Co-operation among States in accordance with the Charter of the United Nations, 1970 (principle of equal rights and self-determination of peoples); United Nations Declaration on the Rights of Indigenous Peoples, 2007, Article 46(1); United Nations Declaration on the Rights of Persons Belonging to National or Ethnic, Religious and Linguistic Minorities, 1992, Article 8(4); Framework Convention for the Protection of National Minorities, 1995, Article 21.

54 See e.g. Crawford, supra note 31, p. 53 .

55 On the increasing role of referenda in this context, see Markku Suksi, 'The Referendum as an Instrument of Decision-Making in Autonomy-Related Situations', in Hilpold (ed.), supra note 5 , p. 97. 
likely violent) process, possibly followed by some degree of recognition by states ${ }^{56}$ or achieving so-called "remedial secession" in response to established patterns of oppression against the group, ${ }^{57}$ testify, at best, to the agnosticism of international law vis-à-vis independence, but do not add any greater weight to the problem in legal or policy terms. Remedial secession lacks widespread support amongst states, and any form of extra-constitutional resistance to central power would ordinarily be treated under international law as insurrectional in nature, with little or no room for enhancing the international legitimacy of the claim. 58

In short, sub-state group aspirations are more likely to receive serious consideration if they work within the structure of the state as they seek to advance their standing in conversation with the government and, possibly, other communities as well. Rather than dwelling on mechanisms of territorial redistribution, it is far more common for international standards or human rights practice relating to, or affecting, group accommodation to be framed in close conceptual and practical connection with ideas of democracy and pluralism.

For example, the signatories states of the CSCE 1990 Copenhagen Document on the Human Dimension (including Turkey) openly recognises that "the questions relating to national minorities can only be satisfactorily resolved in a democratic political framework based on the rule of law", including, crucially, respect for human rights, and political pluralism. ${ }^{59}$ Ten years later this approach is broadly reaffirmed by the United Nations Millennium Declaration, adopted by the General Assembly in 2000; UN member states express their resolve "to strengthen" their capacity "to implement the principles and practices of democracy and respect for human rights, including minority

$5^{6} \quad$ See the Reference case, supra note 38 , para. 142.

57 For discussion, see David Raič, Statehood and the Law of Self-Determination (Martinus Nijhoff Publishers, Leiden, 2002) ch. 7 .

$5^{8}$ The Kosovo case, for example, does not support the remedial secession thesis: Accordance with International Law of the Unilateral Declaration of Independence in Respect of Kosovo, 22 July 2010, ICJ, Advisory Opinion, para. 82, <https://www.icj-cij.org/files/caserelated/141/141-20100722-ADV-01-oo-EN.pdf>, visited on 10 January 2019; see also James Summers, 'The Internal and External Aspects of Self-Determination Reconsidered', in Duncan French (ed.), Statehood and Self-Determination: Reconciling Tradition and Modernity in International Law (Cambridge University Press, Cambridge, 2015) pp. 239-240. On the weakening of the international legitimacy of an unconstitutional attempt at secession, see e.g. the Reference case, supra note 38 , para. 143; secessionist rebels are not entitled to seek and receive support from third states: for a broader discussion about procedural legitimacy, see Antonello Tancredi, 'A Normative 'due process' in the Creation of States through Secession', in Marcelo Kohen (ed.), Secession: International Law Perspectives (Cambridge University Press, Cambridge, 2006) p. 171, at pp. 189-19o.

Section IV, para. 30 . 
rights". ${ }^{60}$ More specific international human rights instruments, such as the United Nations declarations on minorities and indigenous peoples, respectively, and the Council of Europe's Framework Convention for the Protection of National Minorities, all work explicitly on the basis that the web of rights and entitlements that they provide can only operate within a democratic framework. ${ }^{61}$

While there is no definition of "democracy" per se under international law, and calls for a "right to democracy" have remained somehow elusive, both empirically and conceptually, ${ }^{62}$ the link between democracy and pluralism has frequently come to the fore, especially under the European Convention on Human Rights. In Gorzelik v. Poland, for instance, the European Court of Human Rights assertively notes that democracy "is the only political model contemplated in the Convention and the only one compatible with it", and emphasises the role of pluralism as a key internal feature of the concept of democracy. Premised on the need to ensure "the fair and proper treatment of minorities", the Court's view of democratic pluralism takes on political and cultural dimensions, including recognition of entities "seeking an ethnic identity or asserting a minority consciousness". Indeed, pluralism within a democratic system, the Court argues, "is also built on the genuine recognition of, and respect for, diversity and the dynamics of cultural traditions, ethnic and cultural identities". 63

In this context international human rights law prohibits arbitrary limitations by the state on the possibility of group recognition or self-identification and enables a group to make claims within acceptable limits, which are ordinarily defined by socio-historical evidence appropriate to the case, the deployment of non-violent methods of claim-making, and respect for the rights of

6 United Nations General Assembly Resolution 55/2, 8 September 200o, Section v, para. 25.

61 United Nations Declaration on the Rights of Indigenous Peoples, 2007, eighteen preambular para.; United Declaration on the Rights of Persons Belonging to National or Ethnic, Religious and Linguistic Minorities, 1992, sixth preambular para.; Framework Convention for the Protection of National Minorities, fifth preambular para.

62 See e.g. Susan Marks and Andrew Clapham, International Human Rights Lexicon (Oxford University Press, Oxford, 2005) pp. 61-70. As is well-known, proponents of narrow views of democracy in international law as merely a matter of electoral rights and procedures, or otherwise an entitlement to non-discrimination within the political community, have generally refrained from taking internal group accommodation issues seriously. In this sense, the several international instruments referred to in this article suggest, if only implicitly, a much more capacious view of a democratic framework.

63 European Court of Human Rights, Gorzelik v. Poland, Judgment, Application No. 44158/9820, 17 February 2004, paras. 89-93. 
individuals within and outside of the group. ${ }^{64}$ Pluralism is arguably not a call for cultural relativism, but works within parameters that are meant to protect the democratic space itself, however loosely defined, across jurisdictions. ${ }^{65}$ However, whereas political and cultural pluralism stands as a general marker of opposition to mono-cultural views of society, forms of legal pluralism (in the sense of distinct legal regimes solely linked to group membership) challenge conventional ideas of democracy that rest on unitary visions of the internal legal order. ${ }^{66}$ Claims to group-based legal pluralism thus tend to come under closer scrutiny by human rights bodies, ${ }^{67}$ although global and regional trends under human rights law focus on the concrete operation of the regime (e.g. specific indigenous customary laws) and whether any internal reform that may be needed in particular contexts (e.g. specific faith-based personal laws) is being fostered by the state by encouraging an inclusive and participatory process within the community. ${ }^{6}$

In fact, "participation" is a key legal facet to the robust democratic framework assumed by most international standards in the field. The right to be involved in decision-making processes of relevance to the group, and indeed in

64 United Nations Declaration on the Rights of Indigenous Peoples, Articles 33, 46; Framework Convention for the Protection of National Minorities, Article 3; ILO Convention 169 on Indigenous and Tribal Peoples, Article 1(2); United Nations Human Rights Committee, General Comment 23: The Rights of Minorities (Article 27) (UN Doc. CCPR/C/21/Rev.1/ Add.5), 8 April 1994; for discussion, see, for example, Patrick Macklem, 'Indigenous Recognition in International Law: Theoretical Observations', 30 Michigan Journal of International Law (2008-09) p. 177; Joseph Marko (ed.), Human and Minority Rights Protection by Multiple Diversity Governance (Routledge, London, 2019) Section 9.2.1; Josef Marko, 'The Council of Europe's Framework Convention on the Protection of National Minorities and the Advisory Committee's Thematic Commentary on Effective Participation', in Weller (ed.), supra note 45, p. 222, at pp. 234, 242.

65 As noted, the European Court of Human Rights, for example, emphatically works on the basis that the European Convention protects pro-group political and cultural pluralism only to the extent that the latter does not conflict with the democratic values endorsed by the Convention.

66 For examples of this debate from a theoretical and/or legal perspective, see Payero-López and Nimni, supra note 41; Helen Quane, 'Legal Pluralism and International Human Rights Law: Inherently Incompatible, Mutually Reinforcing or Something in Between?', 33 Oxford Journal of Legal Studies (2013) p. 675; Jonnette Watson Hamilton, 'Acknowledging and Accommodating Legal Pluralism: An Application to the Draft Nordic Saami Convention', in Nigel Bankes and Timo Koivurova (eds.), The Proposed Nordic Saami Convention: National and International Dimensions of Indigenous Property Rights (Hart Publishing, Oxford, 2013) p. 45; Ayelet Shachar, 'Entangled: family, religion and human rights', in Cindy Holder and David Reidy (eds.), Human Rights: The Hard Questions (Cambridge University Press, Cambridge, 2013) p. 115.

67 See e.g. Pentassuglia, supra note 44 , pp. 152-153.

68 See e.g. Quane, supra note 66, pp. 687-702. 
public life more broadly, is a constant feature of international (global and regional) articulations of norms applicable to a variety of sub-state groups. ${ }^{69}$ Participation rights can adapt to the area in which they operate (political, socio-economic, cultural), although the gist of such rights in their multiple ramifications lies in an opportunity for an "effective" say in decision-making by the group representatives, or otherwise in real access of group members to a range of public policies. ${ }^{70}$

Under international law "effective participation" is not internally linked to a pre-defined set of institutional mechanisms or policies, as the requirement of "effectiveness" is often taken to be a legally mandatory result that allows for reasonable context-sensitive variations. However, general rights of participation, as stated in Article 25 of the International Covenant on Civil and Political Rights, or general rights to freedom of association, and their attendant grouprelated dimensions (e.g. pro-group political party formation, mother tongue availability of electoral materials, or genuine access to active and passive voting rights), all inform the notion of "effectiveness" as they come to represent some preliminary essentials of participation in the narrower sense of direct involvement in decision-making, beyond tokenistic forms of representation. ${ }^{71}$

The move from general (or generic) participation rights to more targeted mechanisms can be a difficult one to make, not least because of the significant process of cross-fertilisation that has taken place within global, regional and domestic human rights practice, and the consequent blurring of interpretative lines across legal regimes in judicial and non-judicial human rights discourse. ${ }^{72}$ It is reasonable clear, though, that the minimum content that largely defines the general - arguably customary law - dimension of participation rights in this context need to be complemented by an adjustable suite of institutional

69 See the OSCE Lund Recommendations, supra note 7; United Nations Declaration on the Rights of Indigenous Peoples, Articles 4, 18, 19, and 32(2); for a useful review of practice, see also Athanasios Yupsanis, 'Article 27 of the ICCPR Revisited - The Right to Culture as a Normative Source for Minority/Indigenous Participatory Claims in the Case Law of the Human Rights Committee', 26 Hague Yearbook of International Law (2013) p. 359.

70 The Advisory Committee operating under the Framework Convention for the Protection of National Minorities has openly referred to the right as entailing an "obligation of result" upon states: see Marko, supra note 64, p. 239.

71 United Nations Human Rights Committee, General Comment 25: Article 25 (Participation in Public Affairs and the Right to Vote) (UN Doc. CCPR/C/21/Rev.1/Add.7), 12 July 1996; Marko (ed.), supra note 64, Section 9.2; on the issue of using non-Turkish languages in electoral campaigning in Turkey, see Kolcak, supra note 6, pp. 71-72.

72 For an example, see Pentassuglia, supra note 44, pp. 138-139; Marko (ed.), supra note 64, ch. 9 . 
measures from which any credible judgment of the "effectiveness" of group participation (as a factual and legal result) would depend.

It is no coincidence that, over the course of a significant period of time, specialised mechanisms of participation have been identified on a fairly regular basis. Both the OSCE and the Council of Europe, for example, have openly endorsed (without mandating them) forms of proportional representation that can facilitate group representation (including reserved seats in Parliament or other public bodies, or exemptions from electoral thresholds), as well as, crucially, territorial and non-territorial forms of self-government. ${ }^{73} \mathrm{Al}-$ though such mechanisms aim to enhance effective participation within a democratic framework, international standards normally caution against a pervasive ethnification of institutional forms of group involvement.

They are broadly tolerant of political parties based on communal ties, for instance, as long as they are "the only hope for effective representation of specific interests, and thus, for effective participation". ${ }^{74}$ But in less divisive circumstances, there is a sense that the pro-group party will not identify exclusively with the interest of the group and will not define party membership strictly in terms of ethnic or national affiliation. ${ }^{75}$ Similarly, any form of territorial autonomy that is arranged within the state, while instrumentally designed to benefit a minority population that is in the majority within its traditional settlement area, is not construed against exclusivist ethno-national criteria but is rather viewed as an adjustable form of decentralisation of decision-making power within an institutional unit that democratically respects the rights of all individuals and groups within its jurisdiction. ${ }^{76}$ International support for cultural (non-territorial) autonomy, on the other hand, outlines an alternative jurisdictional space in pre-defined areas of significance to the group's identity,

73 Report of the CSCE Meeting of Experts on National Minorities, Geneva, 19 July 1991; Framework Convention for the Protection of National Minorities and Explanatory Report, February 1995, H(95)10, para. 80 (Article 15). Several cases of autonomy arrangements are discussed, for example, in Hannum, supra note 27, Parts II, III; Yash Ghai and Sophia Woodman (eds.), Practising Self-Government: A Comparative Study of Autonomous Regions (Cambridge University Press, Cambridge, 2013).

74 OSCE Lund Recommendations, supra note 7 , Section B.8.

75 However, the Advisory Committee's Thematic Commentary on Effective Participation in Public Affairs is clear that both mainstream parties and those formed by national minorities can play a key role in facilitating participation, since minority involvement in mainstream parties alone may not be sufficient: Commentary on The Effective Participation of Persons Belonging to National Minorities in Cultural, Social and Economic Life and in Public Affairs, 27 February 2008, para. 78.

76 Osce Lund Recommendations, supra note 7, Section III.16. 
such as language and education. ${ }^{77}$ Yet it makes its success dependent upon the existence of a genuine participatory process, involving the central authorities and all sectors of the community, aiming to work out clear criteria around the legal status, competences and financing of the new autonomy bodies. ${ }^{78}$

It is important to note in the context of this analysis that the associative substance and decision-making inclusiveness of the principle of participation, though largely obtained within the jurisdiction of the state, can have important transnational dimensions too. Article 2(5) of the 1992 United Nations Declaration on Minorities recognises "free and peaceful" cross-border contact rights with kin-groups living in other states. Within this parameter, sub-state groups can seek to develop forms of transnational activism that result in either coordinating national organisations through supranational structures (e.g. the Sami Council in Nordic countries) $)^{79}$ or providing a measure of direct input into the work, including standard-setting exercises, of international bodies. ${ }^{80}$ This sort of activity, no matter how influential it can be on the ground, particularly at the level of participation in international decision-making, ${ }^{81}$ remains fundamentally within the ambit of private law-based organisations operating within and across state boundaries. ${ }^{82}$

Far more difficult, though, is the translation of such transnational activity into a specific constitutionally-entrenched regulatory framework that can

77 Malloy and Palermo (eds.), supra note 45.

78 See, for example, the Advisory Committee's Thematic Commentary, supra note 75, paras. 135-136; for a broader comparative assessment and, in particular, the need to secure group involvement and proper accountability within the group, see Federica Prina, David J. Smith and Judit Molnar Sansum, 'National Cultural Autonomy in Central and Eastern Europe: Challenges and Possibilities', in Nimni and Aktoprak (eds.), supra note 9, p. 85.

79 Timo Koivurova, 'Can Saami Transnational Indigenous Peoples Exercise Their SelfDetermination in a World of Sovereign States?', in Bankes and Koivurova (eds.), supra note 66, p. 105 .

8o See e.g. Article $17(2)$ of the Framework Convention for the Protection of National Minorities.

81 For the work of the Sami Council as a representative of voluntary Sami associations from Finland, Russia, Norway and Sweden, see the official website at $<$ http://www.saamicouncil.net $>$, visited on 13 January 2020.

82 This does not rule out the possibility of the relevant entities being endowed with specific public tasks or powers by the state: in the context of cultural (non-territorial) autonomy, see Markku Suski, 'Non-Territorial Autonomy: The Meaning of '(Non-)Territoriality', in Malloy and Palermo (eds.), supra note 45, p. 83, at pp. 92-93, 101-103. Interestingly, Suski reviews models of cultural autonomy in Estonia, Finland and Serbia and remarks more broadly: " $[\mathrm{w}]$ hat is striking in relation to the principles of self-determination and sovereignty of the state is that the non-territorial autonomies organized as cultural autonomies have several degrees of freedom as concerns cross-border and international activities in comparison with regular territorial autonomy" (p. 114). 
enable its simultaneous and permanent institutionalisation within state jurisdictions. Examples of this kind are few and far between. The 2005 Draft Nordic Saami Convention, produced by Norway, Finland and Sweden together with their respective Saami parliaments, represents one such example in that it provides a hybrid model of joint governance of communal practices (including a blend of territorial and cultural autonomy) and state laws within an overarching treaty framework..$^{83}$ Some form of cross-border regulative dimension based on a choice and recognition of group belonging was put forward by the Badinter Commission as one possible implication of self-determination across state boundaries in the post-Yugoslav space, and was partly endorsed by the Dayton Agreement that ended the war in the former Yugoslavia. ${ }^{84}$ However, these (tentative) examples indicate that, if anything, any sustained and systematic cross-border framework is ordinarily a function of advanced regional intergovernmental cooperation and/or some form of regulated kin-state involvement rather than group self-management per se.

Whatever graduated levels of pluralism and participation are enjoyed by sub-state national groups, they should not be seen as stepping-stones towards some inflexible end state defined by the group - be it independent sovereignty or a unique (non-negotiable) idea of self-government that overwhelmingly priorities separation over social cohesion. The OSCE Ljubljana Guidelines on Integration of Diverse Societies aptly remind us that:

[I]t is essential for societies to find the appropriate balance between the degree of separation that is necessary to the free expression and development of diversity on the one hand and the establishment and strengthening of links between and among the diverse communities of a society as a whole on the other. ${ }^{85}$

Importantly, they go on to envisage a comprehensive process whereby majorities and minorities engage with one another "through negotiation and mutual accommodation":

Such negotiations should be conducted within institutional and procedural frameworks that enable effective participation and fair decisionmaking. In addition to offering a greater chance of successful outcomes,

83 See Hamilton, supra note 66.

84 For commentary, see Bell, supra note 45, pp. 225-226; for a degree of institutional crossborder exchanges under the 1998 Good Friday Agreement concerning Northern Ireland, see ibid., p. 115 .

85 The Ljubljana Guidelines supra note 50, Section II.7. 
the simple act of engaging in genuine negotiation can enhance participation by all groups in society. 86

These statements are in keeping with the opportunities and constraints of the international law framework. From the internal perspective of sub-state nationalist aspirations, they arguably intimate what Neil Walker has referred to as "reflexive nationalism", meaning an approach to claims that is based on continuing efforts by the group to negotiate the terms of their accommodation rather than the teleological pursuit of a pre-defined modality of recognition, particularly in relation to specific ideas of self-government. ${ }^{87}$

This proceduralist view of diversity management ties up, directly or indirectly, with evolving contemporary accounts of self-determination that, prompted primarily by constitutional court pronouncements, ${ }^{88}$ emphasise the dialogic institutional process of giving some form of recognition to well-supported substate national claims, under conditions to which most, if not all, of the above human rights standards contribute to varying degrees. ${ }^{89}$ Such a comprehensive, relational process requires serious consideration of, at least, the group's ability to effectively articulate its claim - i.e., to have a proper say in that process - the justifications for particular institutional mechanisms of accommodation like self-government, as well as operational issues associated with the claim, including respect for the rights of others. ${ }^{90}$

With this in mind, the following section goes back to the components of the democratic autonomy proposal put forward by the Kurdish movement in order to examine, not Turkey's human rights obligations per se, but rather the

$86 \quad$ Ibid., Section II.8.

87 Walker, supra note 13, p. 163 .

88 The Reference case, supra note 38; Xabier Arzoz and Markku Suksi, 'Comparing Constitutional Adjudication of Self-Determination Claims', 25 Maastricht Journal of European and Comparative Law (2018) p. 452; Walker, supra note 13. But see also, arguably implicitly, Legal Consequences of the Separation of the Chagos Archipelago from Mauritius in 1965, 25 February 2019, ICJ, Advisory Opinion, para. 144, <<https://www.icj-cij.org/files/caserelated/169/169-20190225-01-0o-EN.pdf $>$, visited on 15 February 2020.

89 For some earlier articulations of similar views from an international law perspective (post-Reference case), see Benedict Kingsbury, 'Reconstructing Self-Determination: A Relational Approach', in Pekka Aikio and Martin Scheinin (eds.), Operationalising The Right of Indigenous Peoples to Self-Determination (Institute for Human Rights/Åbo Akademi University, Turku/Åbo, 200o) p. 19; Jan Klabbers, 'The Right to Be Taken Seriously: SelfDetermination in International Law', 28 Human Rights Quarterly (2006) p. 186; Bell, supra note 45 , chs. 5,11 .

9o For reflections on this process, see Gaetano Pentassuglia, 'Self-Determination, Human Rights, and the Nation-State: Revisiting Group Claims through a Complex Nexus in International Law', 19 International Community Law Review (2017) p. 443, at p. 471 et seq. 
close interface of the democratic autonomy concept with that view of selfdetermination as a significant trend in international human rights law.

\section{Democratic Autonomy as Internal Self-determination in Turkey}

\subsection{What Trans-border Autonomy?}

I have already noted that whatever secessionist ambitions existed in the early days of the Kurdish movement led by the PKK (largely echoing the anti-colonial struggle at the time in Africa and Asia), ${ }^{91}$ the democratic autonomy proposal does not rest on a - present or future - claim to independence for Kurdistan or southeast Anatolia in Turkey. As a self-determination aspiration, this is essentially a claim to internal reform, with a cross-border dimension. ${ }^{92}$

In this sense, the development of a federal or confederal structure across Kurdistan that is entailed by the idea of "democratic confederalism" not only works across existing state boundaries, but represents an attempt to amplify, in terms of institutional voice and leverage, a series of internal self-determination claims built around the concept of democratic autonomy. ${ }^{93}$

While ruling out secession or independence taps into international law's ultimate hostility towards the undermining of states' territorial integrity (i.e. aside from operational challenges), it is unclear the extent to which international law can work towards supporting the cross-border dimension that is at the heart of democratic confederalism. As indicated in the previous section, elements of transnationalism in articulating forms of group accommodation are (or can be) embedded in international human rights standards or ad hoc regulatory frameworks, so much so that group participation in international

$91 \quad$ Cengiz Gunes and Welat Zeydalioğlu note that the Kurdish question became increasingly articulated as a case of colonialism in the late 196os: 'Introduction: Turkey and the Kurds', in Gunes and Zeydalioğlu (eds.), supra note 2, p. 3.

92 The idea that the Kurds in Turkey might claim a right to "remedial secession" in light of the oppression they face remains legally untested and is definitely beyond the parameters of the democratic autonomy proposal. However, as noted earlier, even latest developments do not support the remedial secession theory in international law: see supra 58 . For a recent view that nevertheless briefly alludes to, without discussing, this possibility, see Gudmundur Alfredsson, 'The Right of Self-Determination in International Law', in Akbulut and Aktoprak (eds.), supra note 8, p. 28.

93 In the Preface to the 'Contract' approved by the Union of Kurdistan Communities' in 2005 (see supra note 16) Ocalan's idea of self-determination is essentially equated to "non-state self-government", which in turn makes "democratic confederalism" essentially the external projection of self-government arrangements within each of the relevant Middle Eastern states. 
activities of relevance to them has been incorporated in individual models of non-territorial autonomy ${ }^{94}$ and could be seen as an external feature of selfdetermination accommodation within the state. ${ }^{95}$

One may question, though, whether democratic confederalism per se could go beyond a complex web of private law-based arrangements across the Kurdistan region that, provided its internal conformity with human rights standards, offers a useful ("free and peaceful") platform for cross-border networking, management and advocacy. This would essentially expand on existing mechanisms as outline above, and would arguably enrich the level of economic and educational exchanges that are already in place in the Kurdistan region (particularly between Turkey and northern Iraq). ${ }^{96}$ However, when we move from the grass-root level or private sphere of activity to the institutionalisation of a cross-border self-government structure in the public sphere, the lack of any serious prospect of advanced regional intergovernmental cooperation in partnership with the Kurdish communities (through a treaty framework or otherwise), and the obvious lack of a kin-state, render democratic confederalism as a constitutional (formally entrenched) device across borders unrealistic.

\subsection{Rethinking Pluralism and Participation}

If democratic autonomy in practice falls back on the need for a state framework within which the accommodation of Kurdish aspirations must be achieved, then its close conceptual link with the sort of societal pluralism required by contemporary understandings of internal self-determination represents the most obvious baseline from which to assess its internal consistency with international law.

In this respect the broad notion of democratic nation (internal and external to Kurdish communities) on which the idea of democratic autonomy rests, whatever legal qualifications may attract from a human rights standpoint, undoubtedly reflects the element of self-identification as a key source for establishing the existence of a community as a socio-cultural, or indeed "national" reality under customary international law, regardless of state classifications. Virtually all pro-Kurdish political parties, especially the most recent representative of them in Turkey, the HDP, have advocated a solution to the Kurdish question on the basis of a revised pluralistic constitution that recognises an

\footnotetext{
94 See Suksi, supra note 82.

95 See e.g. Leena Heinämäki, 'The Nordic Saami Convention: The Right of a People to Control Issues of Importance to Them', in Bankes and Koivurova (eds.), supra note 66, pp. 141-145.

$96 \quad$ Klein, supra note 2, p. 51.
} 
inclusive notion of citizenship and national identity that is capable of recognising and accommodating different group identities within the boundaries of the state. ${ }^{97}$

When we compare the hybrid blend of civic and ethnic dimensions of Kurdish nationalism with the ambivalence of international law and national adjudicators vis-à-vis sub-state cultural nationalism in the context of claims to selfdetermination of "peoples" (as discussed in section 3.1), it is probably safe to argue that, in the Turkish context, advocating a more plural "self" across society is far more of an institutional urgency than seeking a distinct recognition of the Kurds as the locus of a wholly separate self-determination unit. In other words, an international (self-determination) legal challenge to the culturally monolithic view of the state implied by Article 3 of the Constitution of Turkey, and repeatedly supported by the Constitutional Court, ${ }^{98}$ has less to do with the group's precise international legal status and more to do with opening up a constitutional space for the democratic autonomy proposal to be given serious consideration and recognition. Aside from Turkey's obvious multiple responsibilities, not least the legal obligation to de-securitise the Kurdish question as required by several judgments of the European Court of Human Rights on political party closures, ${ }^{99}$ this ultimately involves a measure of dynamic self-definition and self-recognition by the Kurdish movement itself. 100

Against the backdrop of self-determination/participation standards, ${ }^{101} \mathrm{dem}-$ ocratic autonomy is squarely built around bottom-up control over decisionmaking rather than voting rights per se. "Effective" participation is measured

97 The HDP seeks "the realisation of the constitutional assurance of equality of rights of different identities, languages, beliefs and cultures" (see supra note 12).

98 Oran, supra note 5, pp. 47-49; Bayir, supra note 23, ch. 5; Emre Turkut and Ikboljon Qoraboyev, 'International Law in the Turkish Legal Order: Transnational Judicial Dialogue and the Turkish Constitutional Court', 26 Italian Yearbook of International Law (2017) p. 41. Turkut and Qoraboyev, supra note 98, Section 4.2; Olgun Akbulut, 'A Critical Analysis of Current Legal Developments on the Political Participation of Minorities in Turkey', 17 International Journal on Minority and Group Rights (2010) p. 551; Marko (ed.), supra note 64, Section 9.2.1.

100 As perceptively noted by Neil Walker on the back of current self-determination practice, the recognition of sub-state group aspirations as part of constitutional conversations "works, first and foremost, as an internal feature of the increasingly reflexive character of national political movements and projects - a form of self-recognition" (supra note 13, p. 173). In this sense, the engagement of the Kurdish movement in any future negotiation with the government of Turkey is likely to generate a dynamic self-assessment of the movement itself and what it seeks to achieve.

101 The notion of representative government, or equal access to government, is a starting point for any minimal form of group recognition: see the 1970 UN Declaration on Friendly 
against the actual depth of a democratic process that extends "from the local village and city communes, to the city councils, and to the municipalities and up to the people's congress". 102 This vision of a "dynamic political life" is not immediately linked to active and passive electoral rights on a regional or national levels as it defines "participation" essentially as a form of self-management that is free from state ("undemocratic") interference. ${ }^{103}$ Such a model of "non-state" participation - some kind of self-determination exclusively internal to Kurdish society - discursively reinforces the call for a genuinely pluralistic space that works towards politically empowering the Kurds in Turkey and elsewhere, but does not, and cannot, legally do away with the broader state framework in which democratic autonomy needs to be addressed.

On the one hand, as the case of Yumak and Sadak v. Turkey clearly illustrates, and as the UN Committee on the Elimination of Racial Discrimination has recently confirmed, ${ }^{104}$ the exceptionally high threshold to gain parliamentary representation in Turkey has historically impacted the ability of pro-Kurdish parties (and minority groups more generally) to be represented in government and to actually influence decision-making, despite a significant level of (Kurdish) popular support at the regional level. ${ }^{105}$ Coupled with key

Relations, supra note 53; and more broadly Antonio Cassese, Self-Determination of Peoples: A Legal Reappraisal (Cambridge University Press, Cambridge, 1995) p. 101 et seq.

102 Abdullah Öcalan, Bir Halki Savunmak (Weşanên Serxwebûn, 2004, as translated by Gunes, supra note 8, p. 252).

103 On this view, democracy/participation, and consequently democratic self-government as a form of self-determination, is conceptually decoupled from the "state" or statehood. See e.g. Bezwan, supra note 9, p. 69; Öcalan, supra note 9, p. 469. And to the extent that the primary (political) focus is not on general voting rights, it reflects the core idea of democracy as popular control (supra section 2, note 7) but somehow mirrors debates over narrow(er) or broad(er) views of democracy from a general international law perspective (see supra note 62).

104 European Court of Human Rights, Yumak and Sadak v. Turkey, Judgment, Application No. 10226/03, 8 July 2008; United Nations Committee on the Elimination of Racial Discrimination, Concluding observations on the combined fourth to sixth periodic reports of Turkey (CERD/C/TUR/CO/4-6), 11 January 2016.

105 The Racial Discrimination Committee has expressed its concern that "the 10 per cent threshold constitutes an obstacle to the equitable representation of minority groups in political affairs, in particular in elected bodies (arts. 2 and 5)" (supra note 104, para. 31) and recommended that "the State party improve the representation of ethnic groups in public and private life, including revising the 10 per cent threshold target for political parties" (ibid., para. 32). In the Yumak and Sadak case (supra note 104), the European Court conceded that the 10 per cent threshold appeared "excessive" and recommended (in line with numerous Council of Europe texts) that it be lowered, but controversially concluded that it was not in breach of Article 3 of Protocol 1 to the Convention; a solid dissent argued that the Turkish voting system was incompatible with the accommodation of the interests of 
operational aspects of the electoral process, such as the circulation of electoral materials in non-Turkish languages, one can hardly doubt about the close link between effective participation and general participation rights, including general voting rights, as set out, for example, in Article 25 of the ICCPR. ${ }^{106}$ At the same time, we need to distinguish the bottom-up approach to democratic autonomy as a way of creating an associative platform for dealing with a variety of societal concerns internal to the Kurdish-populated areas in Turkey, including representatives of other minority groups, ${ }^{107}$ from the institutional entrenchment of democratic autonomy as one variant or another of selfgovernment. ${ }^{108}$ When applied to the broader state framework, the first line of thinking attracts, again, associative freedoms and basic participation rights in decision-making within a minimally democratic system. It essentially breaks down into a series of societal arrangements governed by private law that, if applied properly, is fully consistent with human rights standards, including forms of internal pluralism. ${ }^{109}$ The second, institutionally ambitious paradigm of democratic autonomy as territorial and/or cultural autonomy as outlined in the previous sections, namely one that involves a measure of decentralisation of decision-making authority under public law or with a public law dimension, calls instead for more complex considerations regarding the justifications and operationalisation of self-government as part of a constitutionally deeper, state-wide self-determination process.

a large part of the electorate that identifies with a national or other minority, and thus exceeded the state's margin of appreciation (Joint Dissenting Opinion of Judges Tulkens, Vajić, Jaeger, and Šikuta, para. 5).

106 In the Human Rights Committee's General Comment 25 (see supra note 71, para. 12), it is noted, for instance, that "[i]nformation and materials about voting should be available in minority languages"; the use of the Kurdish language and its dialects in Turkey's electoral campaigning was one of the language issues addressed by the so-called "Democratisation Package" adopted by the government in 2014: Kolcak, supra note 6, pp. 71-72; see also the 1923 Treaty of Lausanne, Article 39(4) (prohibiting language restrictions on Turkish nationals at, inter alia, "public meetings").

107 An important example of this model of participation is the broad civil society network operating within the framework of the Diyarbakir-based Democratic Society Congress: see Gunes, supra note 8, pp. 261-262.

108 It is worth noting here the suggestion that the rights of participation in Article 25 of the ICCPR can themselves include forms of "local, regional or cultural autonomy" in order to make the participation of certain groups in decision-making effective (United Nations Human Rights Committee, Diergaardt et al. v. Namibia, Comm. 76o/1997 (UN Doc. CCPR/ $\mathrm{C} / 76 / \mathrm{D} / 760 / 1997$ (2000), 69th sess.), 25 July 2000, Separate opinion by Mr Martin Scheinin).

109 Suski, supra note 24. On internal pluralism linked to freedom of association or mechanisms of consultation/participation, or otherwise the wider international human rights law framework, see Marko, supra note 64; Quane, supra note 66, pp. 687-702. 


\subsection{Justifying Democratic Autonomy}

In terms of justifications, the historical legacy of Kurdish self-administration within the Ottoman Empire arguably represents an important strand of current autonomy claims. As clearly shown by a number of historical studies, beginning in the early 16 th century, and regardless of the millet system, Kurdish autonomy was established under the Ottomans in at least three Kurdishpopulated provinces (eyalets) with, respectively, Diyarbakir, Raqqa and Mosul as their administrative centres. The level of autonomy varied depending on the administrative status of the specific entity, although all of them were eventually abolished as a result of the pervasive centralising process of "Turkification" fostered by the late Ottoman elites in the tanzimat era $(1838-1876)$ and reinforced by the emerging Turkish nationalist movement of the early 2oth century. ${ }^{110}$

As noted, the short-lived Turkey's (Kemalist) Constitution of 1921 was adopted one year after the Treaty of Sèvres, which, in line with US President Wilson's idea of autonomy of non-Turkish minorities within the Ottoman Empire, had included a clear legal commitment to a "scheme of local autonomy" for the Kurds. ${ }^{111}$ While the Kemalists behind the 1921 Constitution had rejected the Sèvres reconfiguration of post-Ottoman territories, the 1921 Constitution was not in itself hostile to (Kurdish) autonomy arrangements either, as illustrated by the driving factor behind Article 11, and as additionally (though indirectly) confirmed by the autonomous status granted to the Greek Islands of Imbros and Tenedos under the Treaty of Lausanne, signed by Turkey two years later and implemented by legislation in $1927 .{ }^{112}$ Also, some form of very sporadic self-critical assessment of the historical record by sectors of the Turkish political world in more recent decades, however insufficient to solve the Kurdish question, indicates a certain level of awareness of the connection between past repression and current Kurdish demands. ${ }^{113}$

The democratic autonomy proposal is effectively a way of crossing the bridge between the past and the present by de facto revitalising and ultimately reconceptualising previous international and domestic regulatory frameworks

110 Van Bruinessen, supra note 26, p. 157 ff.; Veli Yadirgi, The Political Economy of the Kurds of Turkey: from the Ottoman Empire to the Turkish Republic (Cambridge University Press, Cambridge, 2017) p. 72 et seq.

111 See supra notes $29,32,33$. The same approach to local autonomy was subsequently confirmed by the Council of the League of Nations in 1925 in relation to the so-called Mosul question, i.e., the question of the Turkish-Iraqi border: see Bring, supra note 5, p. 162.

112 For an assessment of that (still legally valid) experience, see Akbulut, supra note 29.

113 Kolcak, supra note 6, pp. 68-69 (including criticism of the official policy of assimilation and a short-lived call for change in the early 1990s and 2000s). 
and models of accommodation. The Treaty of Lausanne unquestionably represented the point of legal rupture with the Ottoman past that has since been carried over to the subsequent articulations of the Turkish legal order. Although no legal obligation regarding autonomy can be construed as a matter of state succession, treaty interpretation, let alone inter-temporal law, it can still be argued that democratic autonomy is consistent with international law (and the international law of self-determination in particular) in the sense that Lausanne does not in itself prohibit autonomy solutions (just as it does not prohibit an extension of the minority concept as a matter of international and Turkish law). ${ }^{114}$ In other words, from an international law perspective, the historical record of Kurdish autonomy (achieved or proposed) provides important (material) evidence of both the distinctiveness of Kurdish communal existence and the legitimacy and consistency of the current claim to autonomy.

This is even more so if democratic autonomy - understood as a series of graduated forms of accommodation involving Kurdish identity and a degree of decision-making authority, rather than a single, tightly construed idea of self-government - can be said to engage the international law of selfdetermination directly and more ambitiously, at least on two levels. For one thing, in circumstances of sustained conflict like the present one, it is reasonable to believe that some degree of autonomy is the best way, probably the only way, of implementing existing interlocking norms on internal selfdetermination that benefit the Kurds and the country as a whole. ${ }^{115}$ The undisputed lack of a freestanding general right to autonomy under international law does not detract from the recurrent use of autonomy in its various forms as a tool for fulfilling the sort of internal self-determination arrangements

114 The Racial Discrimination Committee has noted that "the Treaty of Lausanne does not explicitly prohibit the recognition of other groups as minorities. The Committee therefore recommends that the State party review its position and consider recognizing other groups that may qualify as being ethnic, national or ethno-religious minorities, such as Kurds, Roma, Ezidis and Caferis" (supra note 104, para. 14). In a broadly similar vein, the United Nations Human Rights Committee expressed its concern about "the discrimination and the restrictions suffered by members of minorities, such as the Kurds and the Roma, affecting their right to enjoy their own culture and use their own language (arts. 2 and 27)", United Nations Human Rights Committee, Concluding observations on the initial report of Turkey adopted by the Committee at its 106th session (15 October - 2 November 2012) (CCPR/C/TUR/CO/1), 13 November 2012, para. 9 .

115 Marc Weller has spoken of a "strong presumption" in favour of autonomy in such circumstances (Towards A General Comment on Self-Determination and Autonomy (UN Doc. E/ CN.4/Sub.2/AC.5/2005/WP.5), 25 May 2005, pp. 13-16); and Christine Bell, supra note 84, p. 225, has similarly argued that autonomy arrangements as part of what she calls hybrid self-determination can be "the best application of the law in situations of intrastate ethnic conflict". 
referred to in the Reference case - indigenous autonomy being only one instance of such practice. ${ }^{116}$

More broadly, democratic autonomy goes a long way towards correcting injustices caused by the abandonment of the 1920 Sèvres arrangements by the international community and the domestic reshaping of the Kurdish question as a matter of forced assimilation, state-sponsored violence, and ultimately unequal access to government in the aftermath of the Treaty of Lausanne. While this background may or may not militate in favour of transforming Turkey into a specific binational state, it certainly shows the extent to which these treaty settlements implicate international law in distributing sovereign authority in post-Ottoman territories, and the continuing effects of such reshaping of the Kurdish question over the last century.117

Finally, the democratic autonomy proposal is the reflection of a resilient and long-standing articulation of Kurdish autonomy demands in Turkey's public discourse, despite the lack of region-wide referenda in Kurdish-populated areas. Whatever variations may exist in the way democratic autonomy is understood within the Kurdish movement, its overwhelming support for solutions that are built around the recognition of Kurdish identity and decentralisation of power that can benefit the Kurdish community is well-established. ${ }^{118}$ This clearly expressed view should be given serious consideration and some form of recognition as part of a comprehensive and relational internal self-determination process in the sense indicated above, namely a process of

116 United Nations Declaration on the Rights of Indigenous Peoples, Article 4; in addition to the analyses offered in the preceding note, see the wide range of practical examples of autonomy arrangements, supra note 73 .

117 The point here is informed by both distributive justice dimensions (for a broader argument, see, for example, Patrick Macklem, The Sovereignty of Human Rights (Oxford University Press, Oxford, 2015), chs. 5, 7) and the notion that Lausanne can and should be interpreted, not in isolation from contemporary human rights standards, but in light of the evolving norm of internal self-determination (e.g. Vienna Convention on the Law of Treaties, Article 31(3)(c)). In other words, the 1923 Lausanne regime should no longer be seen as a valid platform for legally insulating the Kurdish question (if it ever was possible to see it in that way back then) and de facto enabling anti-Kurdish repressive policies (see also supra note 114); on the contrary, democratic autonomy can be regarded as a way of remedying the effects of those continuing (current) unequal policies by achieving a measure of internal self-determination as increasingly recognised under international human rights law.

118 Virtually all sectors of the Kurdish movement in its multiple and diverse articulations have repeatedly called for such solutions since the establishment of modern Turkey. In Turkey's latest general election (June 2018), the HDP managed for the second time to pass the 10 per cent threshold on a similar political platform, as far as the Kurdish question was concerned. 
negotiation that is triggered by established national group demands (in line with the Reference case) $)^{119}$ and pursues the effective involvement of the group and the wider objective of mutual accommodation. ${ }^{120}$

\subsection{Implementing Self-government}

In operational terms, the self-government model embraced by the democratic autonomy proposal is reinforced not only by the actual practice of associative (personal) autonomy fostered by leading Kurdish civil society organisations, but also by the special significance attached by pro-Kurdish political parties in Turkey to the Council of Europe's 1985 European Charter of Local Self-Government (ECLS, to which Turkey is a party). Based on ideas of decentralisation of power from the centre to the local level, the treaty embraces a broad notion of territorial administration:

Local self-government denotes the right and the ability of local authorities, within the limits of the law, to regulate and manage a substantial share of public affairs under their own responsibility and in the interests of the local population. ${ }^{121}$

In more recent years such a broad notion has been adopted as a template for challenging the overly centralist structure of the state and as a contribution to its democratisation consistent with the principle of subsidiarity in the European space. ${ }^{122}$ However, while all sectors of the Kurdish movement - from the PKK to the HDP - strongly endorse power decentralisation and do so in ways

119 The Reference case, supra note 38 (the Court insisted at several junctures on the need for Quebec's claim to be backed by a "clear majority" of Quebecers; while the claim in this case was one of secession, the democratic and legitimacy-related logic of the Court's point arguably applies by analogy to autonomy claims within the state).

120 See supra, Section 3.2.

121 ETS No.122, 1985, Article 3(1). It entered into force in Turkey on 1 April, 1993.

122 Article 4(3) states that: "Public responsibilities shall generally be exercised, in preference, by those authorities which are closest to the citizen". The Council of Europe has drawn upon this principle through later resolutions involving national minorities: for a review, see for example, Bill Bowring, 'Enhanced Local Self-government as a Means of Enhancing Minority Governance', in Weller (ed.), supra note 45, pp. 671-672. The principle of subsidiarity made its appearance within the European Union framework under the 1997 European Union's Amsterdam Treaty and was then reinforced under the 2007 Treaty of Lisbon. It has been noted that the mechanism as it stands, by recognising sub-state cultural and linguistic identities and enhancing the role of sub-state and regional parliaments in the Union's decision-making, can "provide an institutional answer for greater autonomy of sub-state political entities in the EU" (Jacint Jordana, Adam Halesch, Michael Keating, Axel Marx and Jan Wouters, 'Self-determination and the reconfiguration of the nationstate in Europe', in Keating et al. (eds.), supra note 13, p. 259). 
that highlight the enhanced participatory standing of any future territorial self-government unit, the HDP's and its immediate predecessors' flexible use of the democratic autonomy proposal in the context of a general regionalisation of the country somehow distinguishes itself from the more structured and specific localism across Kurdish areas articulated by the PKK - from villages and neighbourhoods to higher levels of administration.

From a self-determination perspective, the operational form of selfgovernment is inevitably a function of the "specific historical and territorial circumstances" of the country, ${ }^{123}$ and there is in principle no international legal impediment to forms of sub-regional autonomy being seen as part of any future structure of self-government. While most relevant international standards explicitly or implicitly allow for solutions across all levels of sub-state government, and the ECLS itself is not prescriptive about the particular tier of "local authority" to which regulatory and management responsibilities are to be assigned, ${ }^{124}$ there is generally a sense that self-government arrangements relating to group accommodation are primarily concerned with regional autonomy rather than self-government at municipal or village level. ${ }^{125}$ The 1992 UN Declaration on minorities, for example, explicitly links up the right to effective participation in decision-making with the "regional level" concerning the group or the "regions" where the group's members live (Article 2(3)). It is arguably far more common in self-determination peace settlement practice or broader national practice for forms of municipal self-administration to be linked, by way of exception, to the specific ethnic demographics of the municipality or municipalities in question (somehow echoing the hybrid status of towns and cities from post-war period settlements), ${ }^{126}$ or otherwise to locally tailored competences of cultural self-government (close to, yet institutionally separate from the broader municipal level of authority), ${ }^{127}$ or unfortunately to be side-lined entirely as a result of top-down (centrally controlled) processes of regionalisation. ${ }^{128}$

\footnotetext{
123 CSCE Copenhagen Document on the Human Dimension, 1990, para. 35 .

124 Article 4(3)(5), for example, implies that powers can be delegated to sub-regional authorities as well.

125 By commenting on the Lund Recommendations (supra note 7), Bill Bowring notes that "self-governance" in this context is mainly understood in terms of regional arrangements (Bowring, supra note 124, p. 669).

126 For examples, see Weller, supra note 115, p. 7.

127 Suksi, supra note 82; see also Athanasios Yupsanis, 'Minority Cultural Autonomy in Slovenia, Croatia and Serbia: A Real Opportunity for Cultural Survival or a Right Void of Substance?', 12 Europäisches Journal für Minderheitenfragen (2019) p. 83.

128 On the impact of Russia's implementation of the European Charter of Local SelfGovernment on national minorities, see Bowring, supra note 124, p. 678.
} 
In short, the territorial dimension of the democratic autonomy proposal does require a careful balance between a purely jurisdictional, group identity-blind redistribution of decision-making authority across the country and a highly localistic (and potentially vertically centralist) administrative pattern exclusive to Kurdish areas. ${ }^{129}$ At the same time, the element of accountability to and direct participation of the local population, both of which are at the heart of democratic autonomy, must be taken seriously as graduated forms of internal self-determination. In this respect, the additional element of cultural (non-territorial) autonomy to the democratic autonomy proposal which is designed to accommodate all Kurdish sectors of society (and possibly other groups) regardless of their settlement area - appeals precisely to this drive for grass-root democracy and involvement, at least in matters of vital interest to Kurdish identity. One may question whether cultural autonomy, whatever its current empirical record, ${ }^{130}$ can achieve "stateless democracy" (state-free interference), ${ }^{131}$ but it is most certainly the case that territorial and/ or non-territorial arrangements are fully consistent with (indeed, required by) the international law of self-determination as long as they both operationalise effective participation rights and are thus both made part of sustained constitutional conversations over the concrete form of recognition the democratic autonomy proposal should be given in Turkey.

This dynamic interaction between structural changes affecting the country as a whole and crafting a solution specific to the Kurds in Turkey can re-emerge on a smaller scale in the context of debates over the extent to which the democratic autonomy proposal can be reconciled with the rights of others as part of a genuinely pluralistic and relational process of internal self-determination. As discussed in section 2 , to the extent that democratic autonomy seeks to achieve territorial self-government, it is a proposal that instrumentally benefits Kurdish majority areas through the reallocation of competences from the centre as a result of a negotiated and delimited decentralisation of power (delegation/ devolution, etc.), not a claim to an ethno-centric model of accommodation. This is entirely consistent with the international conceptualisation of territorial autonomy. As hinted at above, the 1999 OSCE Lund Recommendations, for example, are clear that, whatever the form of self-governance arrangements,

\footnotetext{
129 It is not unreasonable to assume that a tight link of lower to higher layers of (self-)government could in practice favour a robust centralisation of power over the diverse concerns of local communities.

130 Its current record is quite a mixed one: see Prina et al., supra note 78; Yupsanis, supra note 129; see also Alexander Osipov, 'Autonomy as Symbolic Production: The Case of Contemporary Russia', in Malloy and Palermo (eds.), supra note 45, p. 179.

131 Gunes, supra note 8, p. 258.
} 
"in no case is this to include an ethnic criterion for territorial arrangements",132 and that the self-government unit must operate on the basis of democratic principles to ensure that it "genuinely reflects the views of the affected population", including any minorities within. ${ }^{133}$ More broadly, democratic autonomy conceptually works on the basis that it must either respect the rights of all inhabitants of Kurdish-majority areas (territorial administration) or otherwise constitute a model of accommodation that can, where appropriate, be replicated across the entire spectrum of minority groups in order to entrench pluralism and group diversity throughout the state (cultural autonomy/broad group recognition). ${ }^{134}$

This is again in line with the expectations of a serious self-determination process that accounts for the individuals and groups affected within and outside of the wider political community concerned, but also one that is capable of negotiating distinctive jurisdictional spaces that govern the relationship between the state and the group. Just as the Reference case appeals to the interplay of federalism, democracy, the rule of law and the protection of minorities to articulate the complex web of institutional and social relationships underlying the domestic and international law position of Quebec within Canada, ${ }^{135}$ so too has the European Court of Human Rights (and other human rights bodies) openly embraced a notion of militant democracy that protects claims to robust forms of sub-state group accommodation as long as they themselves are compatible with democracy, particularly by retaining the role of the state in affording remedies for individual rights violations or encouraging accountability and pluralism within the group. ${ }^{136}$

In light of the OsCE Ljubljana Guidelines, the operational viability of the democratic autonomy proposal as part of an international law-based internal self-determination settlement ultimately hinges on a carefully thought-out balance between community institutional separation and overall societal cohesion, a process of "mutual accommodation" that combines bottom-up group participation and state-led diversity management.

132 See the osce Lund Recommendations, supra note 7, Section III.14, Explanatory Note.

133 Ibid., Section III.16.

134 The Democratic Society Congress (supra note 107), for example, endorsed the notion of democratic autonomy as being based on "regional and local structures that allow for the expression of cultural differences": Ahmet Hamdi Akkaya and Joost Jongerden, 'Reassembling the Political: The PKK and the Project of Radical Democracy', 14 European Journal of Turkish Studies (2012) p. 9.

135 The Court was clear that none of them could "trump" the others in this process.

${ }_{13} 6$ See, for example, European Court of Human Rights, Refah Partisi and Others v. Turkey, Judgment, Applications Nos. 41340/98, 41342/98 \& 41344/98, 13 February 2003; Marko, supra note 64 . 


\section{Conclusions: Aligning Democratic Autonomy with International Human Rights Law}

In this article I have examined the international legal dimension of the "democratic solution" to the Kurdish question as proposed and thoroughly debated by the Kurdish movement, with particular reference to internal selfdetermination in Turkey. More specifically, I have sought to fill the gap between the political articulation and analysis of the Kurdish democratic autonomy argument and a view of its internal coherence and consistency under international human rights law, regardless of Turkey's international legal obligations. ${ }^{137}$

Following on from a discussion of the main strands of the Kurdish argument and their ramifications in terms of identity recognition, institutional reform, and rights protection for all, I have explored the interface of the democratic autonomy proposal with the conceptual and practical underpinnings of international human rights standards. I have done so by first addressing the legal position of the Kurds as an ethno-cultural or ethno-national community and then considering the international legal background to the Kurdish argument per se. This has been followed by an assessment of the implications of the democratic autonomy proposal for internal self-determination (in Turkey), increasingly understood in international and constitutional legal discourse as a dialogic institutional and relational process designed to give some form of recognition to well-supported sub-state national claims.

Several key elements of the democratic autonomy concept closely engage international human rights standards in general, and the evolving notion of internal self-determination in particular, including the discursive shift from secession or independence to the reconfiguration of the internal regime, the

137 As the articulation of the piece has, I hope, made clear, this approach does not in any way downplay Turkey's treaty and customary law minimum obligations (let alone a "droit de regard" of other states and international institutions over those obligations; for the erga omnes character of self-determination, see e.g., East Timor (Portugal v. Australia), 30 June 1995, ICJ, Judgment, para. 29). In fact, much of the discussion implicitly or explicitly mirrors Turkey's international legal position, including a legal duty to seriously consider Kurdish demands (as set out in section 2) by allowing an effective process of participation by, and dialogue with the Kurdish movement, independently of specific institutional outcomes (for even more preliminary legal "essentials" relating to education in private schools or the non-discriminatory allocation of public funding, see Kolcak, supra note 6, p. 77 et seq.). Rather, the focus of the article - its very purpose - is to engage with the "other side" of the argument - precisely, the Kurdish argument - as a way of deepening one's understanding of what is actually at stake on the Kurdish side and encouraging a legally informed space of reflection that can reach out to the Kurdish movement itself. 
prioritisation of political and cultural pluralism, the emphasis on participation in and community control over decision-making processes, the historical record of the Kurdish conflict and the resilience of Kurdish demands as central justifications for current claims to territorial and non-territorial selfgovernment, broader calls for the decentralisation of power throughout the country, and the inclusive view of Kurdish-populated areas - indeed, Kurdis$\tan$ as a whole - as territories comprising of both Kurdish and non-Kurdish groups.

Other elements would benefit from further conceptual refining. In this context I have argued that, despite the non-ethnocentric notion of "democratic nation" endorsed by the democratic autonomy proposal, the Kurdish argument could have more conceptual and legal purchase by flexibly relating the Kurds as a socio-cultural reality to various multi-layered, legal iterations of Kurdish claims and institutional goals than through the exclusive language of "peoplehood" or "nationhood" per se. I have also argued that radical institutional forms of transnationalism (beyond more limited trans-border contacts) or, conversely, localism, within Kurdish areas, though conceptually possible and legally consistent with the state's territorial integrity, may in practice prove problematic. This is so either because of the lack of advanced regional intergovernmental cooperation and a regulated kin-state involvement as the necessary pre-conditions for a treaty-based regulatory framework (transnationalism), or primarily because self-government arrangements relating to international mechanisms of group accommodation (local self-government) are largely concerned with regional autonomy rather than self-government at municipal or village level (except in fairly specific circumstances). In addition, I have noted that the concept of "non-state" participation (also articulated as a "stateless democracy") rightly appeals to the drive for grass-root involvement and a community-centred approach - arguably the most salient feature of the democratic autonomy proposal - and to that extent, it discursively (strategically) reinforces the call for a pluralistic process that works towards empowering the Kurds in Turkey and across Kurdistan. However, in practice it cannot do away with the state framework within which democratic autonomy needs operating, both in terms of securing greater representation and influence over decision-making through the electoral process, and in the sense of distinguishing democratic autonomy as an associative private law-based platform for addressing concerns within the Kurdish community from the institutional (constitutional) entrenchment of one variant or another of self-government. Cultural (non-territorial) autonomy, deployed as an important complement to any territorial arrangement in Turkey - probably the closest reflection of direct group participation that informs the whole of the democratic autonomy 
proposal - is no exception to that, since it ordinarily neither confers legislative or tax powers on the community nor dispenses with the role of the state in fostering a participatory process that is meant to establish criteria around the legal status, competences and financing of the new entity, as well as affording remedies for breaches of individual rights. ${ }^{138} \mathrm{I}$ have argued that the viability of democratic autonomy in Turkey from an internal self-determination perspective (as dynamically understood in this article) hinges on a process of "mutual accommodation" (in the words of the OSCE Ljubljana Guidelines) that combines bottom-up participation and state-led diversity management.

Needless to say, the current and widely known political scenario in Turkey, which has led inter alia to the imprisonment of significant parts of the proKurdish leadership, ${ }^{139}$ is anything but conducive to such a process. Moving away from the "Kurdish opening" of the pre-2015 political phase, ${ }^{140}$ such political reversal is further compounded by what appears to be an incremental disengagement of Turkey from international human rights institutions, as well as renewed military confrontations within Turkey and across the Middle East. ${ }^{141}$ While the reasons for Turkey's chronic hostility towards a permanent resolution of the Kurdish question and what this tells us about the role of international law in this context can only be the subject of a separate, future analysis, it is fairly clear that the inevitable need for a settlement at some later stage will require not only Turkey's compliance with its own human rights obligations, but also the Kurdish movement's ability to negotiate the accommodation of its aspirations in ways that are consistent with international human rights law. The foregoing assessment suggests that this is more likely to happen through continually adjustable rather than fixed institutional goals, along the legal continuum implicitly or explicitly opened up by the democratic autonomy proposal.

138 Suksi, supra note 84, p. 112; Marko, supra note 64, p. 245; Prina et al., supra 78, pp. 102-103.

139 European Court of Human Rights, Selahattin Demirtas v. Turkey (No.3), Judgment, Application No. 8732/11, 9 July 2019; Selahattin Demirtas v. Turkey (No.2), Judgment, Application No. 14305/17, 20 November 2018. For a succinct review of recent developments including the reversals of gains in addressing the Kurdish question after the two 2015 general elections and the failed military coup from 2016, see Thomas James Phillips, 'The (In-)Validity of Turkey's Reservation to Article 27 of the International Covenant on Civil and Political Rights', 26 International Journal on Minority and Group Rights (2019) pp. 2-4.

140 Elçin Aktoprak, 'Between Authoritarianism and Peace: The Kurdish Opening in Turkey (2013-2015)', in Nimni and Aktoprak (eds.), supra note 9, p. 137.

141 See supra notes 6,7 . 